\title{
A Late Glacial to Holocene record of environmental change from Lake Dojran (Macedonia, Greece)
}

\author{
A. Francke ${ }^{1}$, B. Wagner ${ }^{1}$, M. J. Leng ${ }^{2,3}$, and J. Rethemeyer ${ }^{1}$ \\ ${ }^{1}$ University of Cologne, Institute for Geology and Mineralogy, Cologne, Germany \\ ${ }^{2}$ University of Leicester, Department of Geology, Leicester, LE1 7RH, UK \\ ${ }^{3}$ NERC Isotope Geosciences Laboratory, British Geological Survey, Nottingham, NG12 5GG, UK
}

Correspondence to: A. Francke (alexander.francke@uni-koeln.de)

Received: 12 November 2012 - Published in Clim. Past Discuss.: 21 November 2012

Revised: 31 January 2013 - Accepted: 4 February 2013 - Published: 28 February 2013

\begin{abstract}
A Late Glacial to Holocene sediment sequence $(\mathrm{Co} 1260,717 \mathrm{~cm})$ from Lake Dojran, located at the boarder of the F.Y.R. of Macedonia and Greece, has been investigated to provide information on climate variability in the Balkan region. A robust age-model was established from 13 radiocarbon ages, and indicates that the base of the sequence was deposited at ca. $12500 \mathrm{cal} \mathrm{yr} \mathrm{BP}$, when the lake-level was low. Variations in sedimentological $\left(\mathrm{H}_{2} \mathrm{O}, \mathrm{TOC}, \mathrm{CaCO}_{3}\right.$, TS, TOC/TN, TOC/TS, grain-size, XRF, $\delta^{18} \mathrm{O}_{\text {carb }}, \delta^{13} \mathrm{C}_{\text {carb }}$, $\delta^{13} \mathrm{C}_{\mathrm{org}}$ ) data were linked to hydro-acoustic data and indicate that warmer and more humid climate conditions characterised the remaining period of the Younger Dryas until the beginning of the Holocene. The Holocene exhibits significant environmental variations, including the 8.2 and $4.2 \mathrm{ka}$ cooling events, the Medieval Warm Period and the Little Ice Age. Human induced erosion processes in the catchment of Lake Dojran intensified after $2800 \mathrm{cal}$ yr BP.
\end{abstract}

\section{Introduction}

Although several paleoenvironmental records spanning the entire Holocene already exist from the Balkan region (e.g., Bordon et al., 2009; Wagner et al., 2009; Vogel et al., 2010a; Peyron et al., 2011; Panagiotopoulos et al., 2012), some suffer from poor radiocarbon chronologies (Wagner et al., 2009; Vogel et al., 2010a), or are inconsistent in terms of spatial variability and short-term climate events (Magny et al., 2003, 2009; Tzedakis, 2007; Berger and Guilaine, 2009). Furthermore, significant anthropogenic impact at least since the late Holocene (e.g., Willis, 1994; Wagner et al., 2009;
Aufgebauer et al., 2012; Panagiotopoulos et al., 2012) complicates the reconstruction of climate change in the Balkan region (Vogel et al., 2010a). Additional records with highresolution sedimentary information from this region are needed to get a better understanding of Late Glacial to Holocene climatic variability and anthropogenic activity and their spatial variability. As shown by a comparison of records from lakes Prespa and Ohrid (Leng et al., 2010; Wagner et al., 2010), shallower lakes often react more sensitive to environmental change. Hence, we can assume that Lake Dojran with a maximum water depth $<7 \mathrm{~m}$ provides a valuable record of climatic change and anthropogenic impact at the Balkan region.

Lake Dojran is located at the boarder of the Former Yugoslav Republic of Macedonia (FYROM) and Greece (Fig. 1). A lake-level lowering of $6 \mathrm{~m}$ between 1955 and 2000 was mainly caused by irrigation and canalisation of the former outlet, River Doiranitis (Griffiths et al., 2002; Zacharias et al., 2002; Sotiria and Petkovski, 2004; Manley et al., 2008). This lake level decrease led to eutrophication and is well recorded in the chemical, biological and stable isotope data of the surface sediments (Veljanoska-Sarafiloska et al., 2001; Griffiths et al., 2002). Increasing anthropogenic influence at Lake Dojran from the mid to late Holocene has been inferred from pollen assemblages in sediment cores recovered close to the lakeshore (Athanasiadis et al., 2000). However, the sediments are poorly dated and there were likely variations in the sedimentation rates including major hiatuses, probably due to significant lake level changes, particularly in the lateral coring locations. 


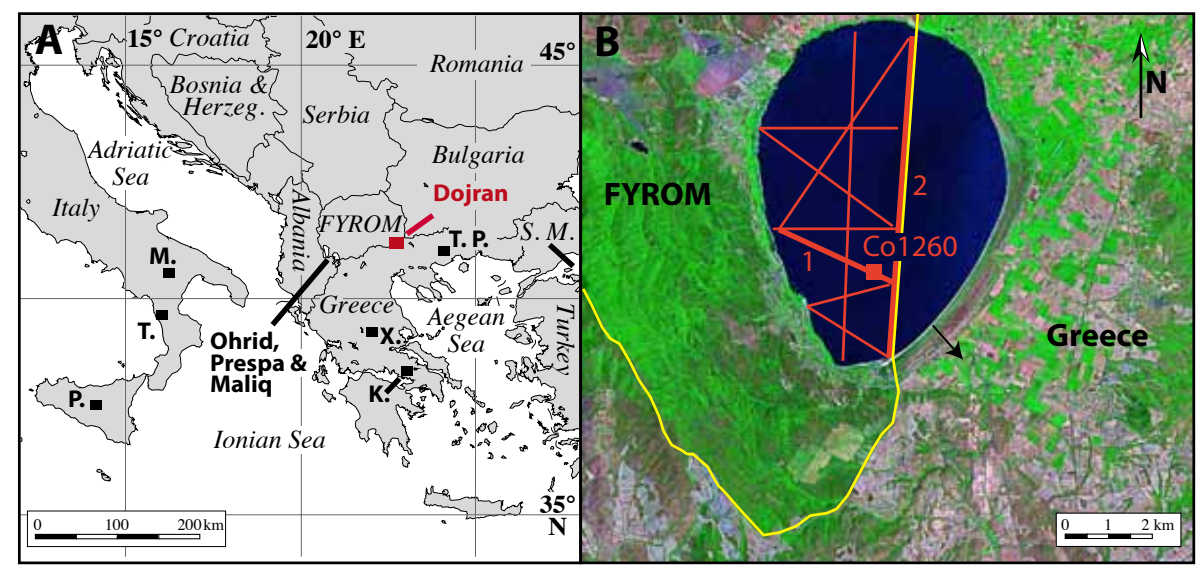

Fig. 1. (A) Locations of Lake Dojran in the northeastern Mediterranean region at the boarder of the Former Yugoslav Republic of Macedonia (FYROM) and Greece. Locations of other paleoclimate records in the region are lakes Ohrid, Prespa, and Maliq, Lake Xinias (X), Lake Kopais (K.), Lago Grande di Monticchio (M.), Lago di Trifoglietti (T.), Lago di Pergusa (P.), Tenaghi Philippon (T.P.), and the Sea of Marmara (S.M.). (B) Satellite image of Lake Dojran with the coring location Co1260 (red square) and the hydro-acoustic profiles. Numbers 1 and 2 mark the hydro-acoustic profiles shown in Fig. 2, the black arrow indicates the position of the former outlet River Doiranitis, and the yellow line shows the border between FYROM and Greece.

\section{Site descriptions}

Lake Dojran (Fig. $1,41^{\circ} 12^{\prime} \mathrm{N}, 22^{\circ} 44^{\prime} \mathrm{E}$ ) is considered to be a relict of the Plio-Pleistocene Peonic Lake, which was formed by volcanic and tectonic activities (Cvijic, 1911; Stojanov and Micevski, 1989). Lake Dojran is located at $144 \mathrm{~m}$ a.s.l. (above sea level) in a carstic depression formed by Paleozoic marble intercalated with phylites (Stojanov and Micevski, 1989). The lake catchment predominantly comprises Paleozoic mica gneiss, muscovite-gneiss and amphibolite, Tertiary volcanic and volcanic-sedimentary rocks, and Quaternary alluvial and limnic sediments (Stojanov and Micevski, 1989; Sotiria and Petkovski, 2004). Only $18 \%$ of the total catchment area of $275 \mathrm{~km}^{2}$ exceeds an elevation of $500 \mathrm{~m}$ a.s.l. The high-elevated regions are in the northeast of Lake Dojran, where the Belisca Mountain range is up to $1870 \mathrm{~m}$ a.s.l. high (Sotiria and Petkovski, 2004). Small rivers, creeks and groundwater drain the catchment area and feed Lake Dojran, particularly during winter and spring (Griffiths et al., 2002; Sotiria and Petkovski, 2004). The former outlet of Lake Dojran, River Doiranitis, which connected the lake to the Axios/Vardar River, is located some metres above the present lake-level. Current water loss from Lake Dojran is due to evaporation and probably to groundwater outflow.

The climate at Lake Dojran is influenced by the Mediterranean Sea via the connection of the Thessaloniki Plain, continental influences and local morphology, leading to a warmer climate with less days with frost compared to other regions in Macedonia (Sotiria and Petkovski, 2004). The mean annual air temperature was $+14.3^{\circ} \mathrm{C}$ between 1961 and 2000 , with monthly average summer and winter temperatures of +26.1 and $+3.7^{\circ} \mathrm{C}$, respectively (Sotiria and Petkovski, 2004). The highest proportion of the annual precipitation
$(612 \mathrm{~mm})$ falls during mild winters (Sotiria and Petkovski, 2004), and dry conditions persist during warm summers.

In 2004, Lake Dojran had a lake water surface area of $40 \mathrm{~km}^{2}$ with water depths between 3 and $4 \mathrm{~m}$ (Sotiria and Petkovski, 2004). However, there are seasonal and longerterm progressive changes that affected the surface area and water depth (cf. Athanasiadis et al., 2000; Manley et al., 2008). Thermal stratification occurs during the summer months (Zacharias et al., 2002), and it is presumed that lake water mixing occurs during winter, similar to Lake Prespa (Matzinger et al., 2006). Due to its location in the carstic depression, Lake Dojran is bicarbonate- and chloride-rich, alkaline and productive (Stankovic, 1931; Griffiths et al., 2002). Today, the littoral area of the lake comprises a fringe of up to $30 \mathrm{~m}$ wide reed beds.

\section{Material and methods}

\subsection{Fieldwork}

Fieldwork at Lake Dojran was carried out in June 2011. A hydro-acoustic survey (Innomar SES-2000 compact, $10 \mathrm{kHz}$ ) on the Macedonian part of the lake (Fig. 1) was used to provide more detailed information on the lake bathymetry and the sediment architecture. At coring location Co1260 $\left(41^{\circ} 11.703^{\prime} \mathrm{N}, 22^{\circ} 44.573^{\prime} \mathrm{E}\right)$ undisturbed, horizontal bedded sediments and a water depth of $\sim 6.6 \mathrm{~m}$ were observed (Fig. 2). Core Co1260 was recovered from a floating platform using a gravity corer for undisturbed surface sediments and a percussion piston corer for deeper sediments (both UWITEC Co., Austria). After recovery, the overlapping $300 \mathrm{~cm}$ long sediment cores were cut into (and up to) 

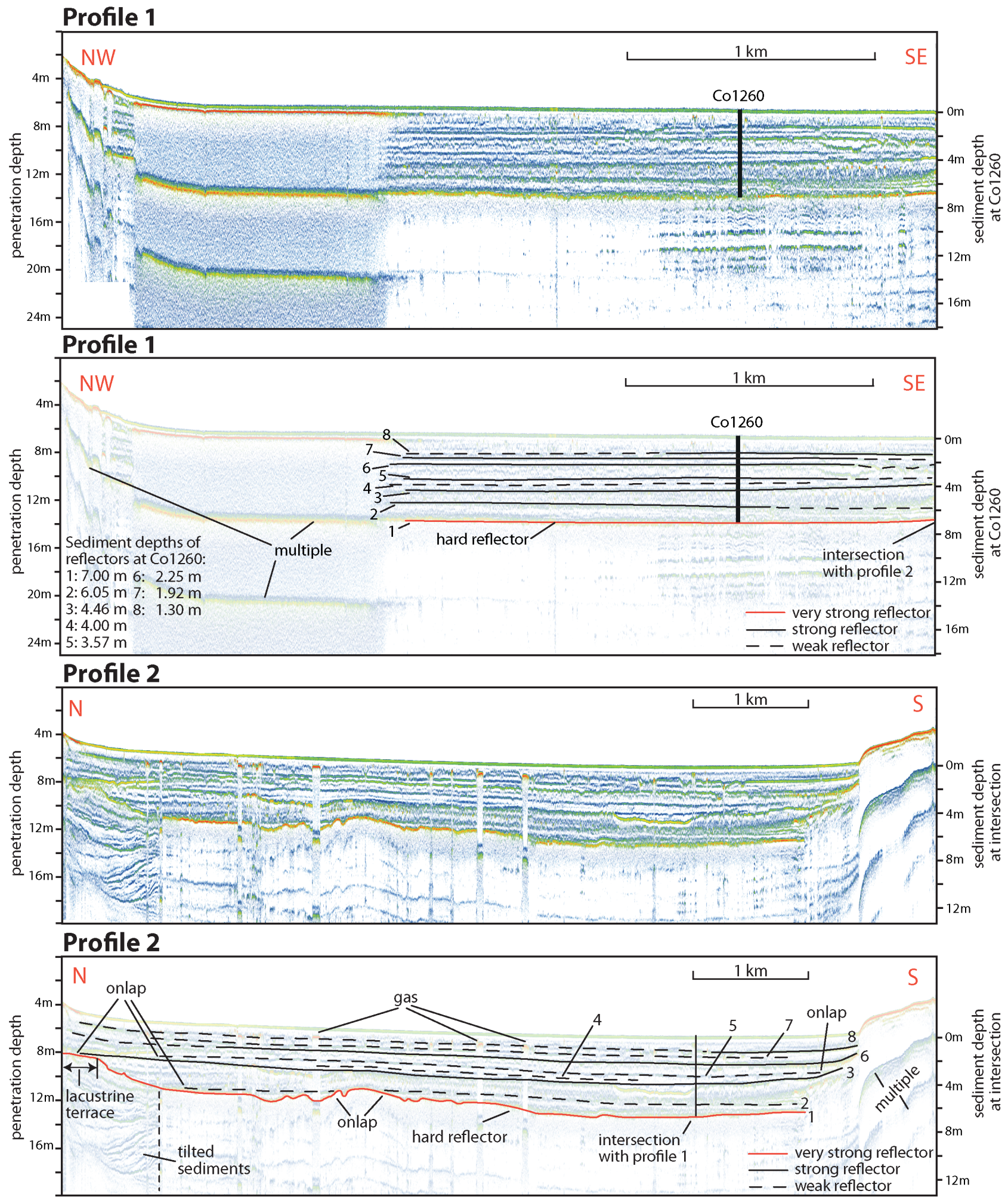

Fig. 2. Un-interpreted and interpreted hydro-acoustic profiles 1 and 2. For location see Fig. 1. The bars to the left indicates depths below lake surface, those to the right depths below sediment surface at the coring location Co1260 (profile 1) or the intersection (profile 2) between the two profiles. The length of the black bar at the coring location Co1260 corresponds to the core length. 
$100 \mathrm{~cm}$ long sections. Core catcher samples were transferred at $2 \mathrm{~cm}$ resolution in plastic vials.

\subsection{Analytical work}

In the laboratory, the cores were split into two halves and one half was sealed airtight for archiving. On the other half, XRay Fluorescence (XRF) scanning was carried out in $2 \mathrm{~mm}$ resolution with an ITRAX core scanner (Cox Analytical Systems, Sweden), equipped with a Cr-tube and a Si-drift detector in combination with a multi-channel analyser. Voltage and amperage were set to $30 \mathrm{kV}$ and $30 \mathrm{~mA}$, respectively. The measured count rates can be used as semi-quantitative estimates of relative concentrations of the detected elements (Croudace et al., 2006). Inaccuracies in comparison to conventional XRF analyses rise due to different resolutions and variations in grain-size, porosity, water content and surface structure of the core.

The sediments were then subsampled in $2 \mathrm{~cm}$ intervals and half of each sample, including those from the core catchers, was freeze-dried. The water content was calculated from the weight loss after freeze-drying. Approximately $1 \mathrm{~g}$ of the dry sediment was treated with hydrochloric acid $(\mathrm{HCl})$, hydrogen peroxide $\left(\mathrm{H}_{2} \mathrm{O}_{2}\right)$, sodium hydroxide $(\mathrm{NaOH})$, and $\mathrm{Na}_{4} \mathrm{P}_{2} \mathrm{O}_{7}$ for grain-size analysis ( $8 \mathrm{~cm}$ resolution) of terrigenous clastic material. Grain-size measurements were carried out with a Saturn DigiSizer 5200 laser particle analyser and a Master Tech 52 multisampler (Micromeritics Co., USA) after one minute of ultrasonic treatment. The data processing of each sample was based on three runs and the GRADISTATv8 programme (Blott and Pye, 2001).

An aliquot of the freeze-dried samples was ground to $<63 \mu \mathrm{m}$ and homogenised for biogeochemical analysis ( $2 \mathrm{~cm}$ resolution). Total nitrogen (TN) and total sulfur (TS) were determined with a Vario Micro Cube combustion CNS elemental analyser (ELEMENTAR Co., Germany). Total carbon (TC) and total inorganic carbon (TIC) were measured with a DIMATOC 200 (DIMATEC Co., Germany). The calcite content $\left(\mathrm{CaCO}_{3}\right)$ was calculated by multiplying the TIC with 8.33 and total organic carbon (TOC) was determined by subtracting TIC from TC.

Isotope studies included modern lake and spring waters ( $\mathrm{O}, \mathrm{H}, \mathrm{C}$ isotopes) and wet sediment samples $(\mathrm{O}, \mathrm{C}$ isotopes $)$ at $4 \mathrm{~cm}$ resolution. For $\mathrm{O}$ isotope composition of modern lake and spring water, the water was equilibrated with $\mathrm{CO}_{2}$ using an Isoprep 18 device for oxygen isotope analysis with a VG SIRA mass spectrometry. A EuroPyrOH-3110 system based on an on-line $\mathrm{Cr}$ reduction method was used for hydrogen isotope analysis. For $\mathrm{C}$ isotope analysis of total dissolved inorganic carbon (TDIC), the inorganic carbon was precipitated during the field work from ca. $85 \mathrm{~mL}$ water using ca. $15 \mathrm{~mL}$ of $\mathrm{NaOH}-\mathrm{BaCl}_{2}$. In the laboratory, the precipitated barium carbonate $\left(\mathrm{BaCO}_{3}\right)$ was washed with deionized water. For isotope analyses, $\mathrm{CO}_{2}$ was extracted from $\mathrm{BaCO}_{3}$ with anhydrous phosphoric acid $\left(\mathrm{H}_{3} \mathrm{PO}_{4}\right)$ under vacuum and the isotopes were analysed using a VG Optima dual inlet mass spectrometer.

For inorganic carbon and oxygen isotope analysis of endogenic calcite, horizons with more than $1 \%$ TIC were bleached with sodium hypochlorite $(\mathrm{NaOCl})$, neutralised and sieved to $80 \mu \mathrm{m}$. After the $<80 \mu \mathrm{m}$ fraction was ground, the extraction of gaseous $\mathrm{CO}_{2}$ and the subsequent measurement followed that described above for TDIC.

Samples for organic carbon isotope analysis were treated with $\mathrm{HCl}$ to remove $\mathrm{CaCO}_{3}$, neutralised, filtered to $20 \mu \mathrm{m}$ and the supernatant was dried at $50^{\circ} \mathrm{C}$. After the $>20 \mu \mathrm{m}$ fraction was ground and homogenised, it was combusted by an Elemental Analyzer (Costech Co., USA) on-line to a VG TripleTrap and Optima dual-inlet mass spectrometer. $\mathrm{CaCO}_{3}$ adjusted TOC content was determined by the elemental analyser. Modern water and sediment isotopic ratios are reported as per mill $(\% o)$ deviations from the VSMOW $(\mathrm{O}$ and $\mathrm{H}$ water) and VPDB (O, C barium carbonate, calcites; $\mathrm{C}$ organics) scales.

Radiocarbon dating on bulk sediment samples, terrestrial plant material, charcoal and biogenic carbonates were carried out by accelerator mass spectrometry (AMS) at the University of Cologne Centre for AMS (Germany) and the ETH Laboratory of Ion Beam Physics in Zurich (Switzerland). Previously, sample pre-treatment and graphitisation was carried out according to Rethemeyer et al. (2013). Organic carbon from bulk sediment, terrestrial plant material and charcoal samples was chemically extracted by acid-alkali-acid extraction (AAA). The alkali extraction was omitted for small samples sizes to avoid loss of sample material. Combustion and graphitisation was carried out with a Vario Micro Cube elemental analyser (ELEMENTAR Co., Germany) coupled to a graphitisation system, where the $\mathrm{CO}_{2}$ is converted to graphite with hydrogen over iron as catalyst. The surface of biogenic carbonates was leached with $1 \mathrm{M} \mathrm{H}_{2} \mathrm{SO}_{4}$ and the carbonate sample was subsequently converted to $\mathrm{CO}_{2}$ by hydrolysis with $99 \% \mathrm{H}_{3} \mathrm{PO}_{4}$ under He. CALIB 6.1.1 (Stuiver and Reimer, 1993) and the IntCal09 dataset (Reimer et al., 2009) were used for conversion of the conventional radiocarbon ages into calendar ages (cal yr BP) on an uncertainty level of $2 \sigma$. Based on the calibrated ages a polynomial age model was established and sedimentation rates were calculated.

\section{Results and discussion}

\subsection{Hydro-acoustic survey}

From the hydro-acoustic survey, profiles 1 and 2 were selected to show the bathymetry and sediment architecture of Lake Dojran (Fig. 2). The bottom morphology of Lake Dojran is relatively simple, with a mean water depth of ca. $6.6 \mathrm{~m}$ and slightly inclining slopes towards the shores (Fig. 2). 
The maximum penetration depth of the hydro-acoustic signal only sporadically exceeds $7 \mathrm{~m}$ sediment depth. One of the spots with deeper penetration is close to the northern shore, where onlap structures and tilted sedimentation below ca. $7 \mathrm{~m}$ sediment depth suggest tectonic activity (Fig. 2, profile 2). In the central basin, a hard reflector occurs at $7 \mathrm{~m}$. This reflector is close to the surface multiple, but has a more undulated shape, particularly in the northern part of the basin. In addition, the multiple in the central basin is slightly deeper, as observed in spots, where hyperbolic reflections with transparent areas underneath indicate the occurrence of gas. At coring location Co1260, parallel, but somewhat undulated reflectors particularly below $7 \mathrm{~m}$ imply sediment thickness of at least $\sim 13.4 \mathrm{~m}$ and do not indicate underlying bedrock. Below this depth, the reflectors are too weak or are overlain by multiples (Fig. 2). The undulated shape of the hard reflector at $7 \mathrm{~m}$ (reflector 1) and the weaker reflections below suggest somewhat disturbed sedimentation as it might have occurred during a lake level lowstand. A terrace in the northern part of the lake (Fig. 2, profile 2) probably represents a paleo-shoreline. The hard reflector at coring location Co1260 is overlain by reflector 2 at $6.05 \mathrm{~m}$ sediment depth, which indicates onlap structures to the hard reflector in the central to northern part of the lake and close to the terrace (profile 2, Fig. 2). Reflector $3(4.46 \mathrm{~m})$ indicates onlap structures only at the terrace close to the northern shore (Fig. 2). Reflector 4 $(4.00 \mathrm{~m})$ pinches out in central areas of the lake and suggests minor lake level fluctuations or the occurrence of lake internal currents, such as observed in Lake Prespa (Wagner et al., 2012). Reflectors $5(3.57 \mathrm{~m})$ and $6(2.25 \mathrm{~m})$ span almost the entire lake basin and were likely formed when the lake level was higher. Reflector 7 (1.92 m) pinches out again, whilst reflector $8(1.30 \mathrm{~m})$ can be observed in marginal parts of the lake and, thus, indicates a somewhat higher lake-level.

\subsection{Lithostratigraphy and biogeochemistry}

Based on visual core description, XRF data and water content, the correlation of the overlapping segments of core Co1260 led to a composite profile of $717 \mathrm{~cm}$ length, which has been subdivided into four lithofacies (Fig. 3).

Lithofacies $1(717$ to $658 \mathrm{~cm})$ is grey, has a low water content and a crumbly structure due to a high abundance of clay clasts. The sediment is poorly sorted, mainly with coarse silt with sporadic drop stones. Aquatic or terrestrial macrophyte remains are not apparent, and the amount of finely dispersed organic material (OM) is low, as indicated in TOC $<1 \%$ and $\mathrm{TS}<0.5 \%$. TOC/TN varies between 3 and 12 and suggests that $\mathrm{OM}$ is mainly of aquatic origin, however, ratios $<4$ can be associated with selective decomposition of TOC (Leng et al., 1999). A high TOC/TS in the lowermost $17 \mathrm{~cm}$ of lithofacies 1 indicates well-oxygenated bottom water conditions and surface sediments (cf. Müller, 2001; Wagner et al., 2009). The $\mathrm{CaCO}_{3}$ content of lithofacies 1 varies between 5 and $20 \%$, and is mainly derived from endogenic calcite, as shown by SEM (Fig. 4). Additional sources of $\mathrm{CaCO}_{3}$ include ostracodes and shells or shell fragments of bivalves, such as at $\sim 664 \mathrm{~cm}$ depth. Postsedimentary dissolution of calcite can be excluded at least for the upper part of lithofacies 1 (ca. 682-658 cm), because the sediments contain well-preserved ostracodes (determined F. Viehberg). Potassium (K) and iron (Fe) counts from XRF analyses, which can be associated with clastic sediment supply (Cohen, 2003; Arnaud et al., 2005), are low, but might be an artifact of the crumbly structure of the core surface. The lowermost section of lithofacies 1 , where $\mathrm{CaCO}_{3}$ is $<9 \%$ and the mean grain size is highest (Fig. 3), corresponds to the hard reflector (reflector 1) in the hydro-acoustic profiles at $7 \mathrm{~m}$ sediment depth.

Lithofacies $2(658$ to $520 \mathrm{~cm})$ is grey to olive grey, has an increasing water content and a massive structure. The grainsize composition is dominated by medium to very coarse silt, which indicates high transport energy due to low water depths or high inflow. Sporadic fine sand lenses are interpreted as ice rafted detritus (IRD). Lithofacies 2 has been sub-divided into lithofacies 2a $(658$ to $590 \mathrm{~cm})$ with finegrained sediments, relatively high $\mathrm{OM}$ and TOC/TN and lithofacies $2 \mathrm{~b}(590$ to $520 \mathrm{~cm})$ with coarser sediments, lower OM and TOC/TN. Similar patterns of TOC and TS suggest that TS derives mainly from OM, however, a low TOC/TS and a good correlation between TOC/TS and Fe throughout lithofacies 2 suggest that TS is partly derived from pyrite (Wagner et al., 2006, 2009). Plant remains or carbonate fossils are not apparent in lithofacies $2 \mathrm{a}$ and $2 \mathrm{~b}$. The transition of lithofacies $2 \mathrm{a}$ to $2 \mathrm{~b}$ likely corresponds to reflector $2(6.05 \mathrm{~m})$ in the hydro-acoustic profiles.

Lithofacies $3(520$ to $265 \mathrm{~cm})$ is olive grey, has a water content between 55 and $70 \%$, and a massive or marbled structure. Grain-size is dominated by medium and coarse silt. A TOC increase from around $1 \%$ at the base to ca. $3 \%$ at the top implies decreasing decomposition or increasing lake productivity, which is, however, only partly reflected in small variations in TOC/TN. Increasing lake productivity is better indicated in $\mathrm{CaCO}_{3}$ of up to $40 \%$, which anti-correlates with $\mathrm{K}$ and $\mathrm{Fe}$ counts. The variations in $\mathrm{CaCO}_{3}, \mathrm{~K}$, and $\mathrm{Fe}$ counts form the sub-division of lithofacies 3 (Fig. 3). Lithofacies $3 \mathrm{a}$ $(520$ to $401 \mathrm{~cm})$ is massive or marbled and has high $\mathrm{CaCO}_{3}$ and low K counts. Shell fragments and well-preserved Dreissena bivalves occur sporadically between 505 and $404 \mathrm{~cm}$ and are more common at 503 and $404 \mathrm{~cm}$ (Fig. 3). In the lower part of lithofacies $3 \mathrm{a}(520$ to $460 \mathrm{~cm})$ TS increases to $1 \%$. SEM analyses showed a high abundance of pyrite (Fig. 4), although this does not correlate with Fe counts, which probably indicates that $\mathrm{Fe}$ is bound in other chemical compounds above and below the TS increase. Lithofacies $3 \mathrm{~b}(401$ to $390 \mathrm{~cm})$ is massive, has minimum $\mathrm{CaCO}_{3}$, which is anti-correlated with $\mathrm{K}$ and $\mathrm{Fe}$ counts, and has a maximum in grain-size distribution. In lithofacies 3c (390 to $265 \mathrm{~cm}$ ), which is also massive, $\mathrm{CaCO}_{3}$ increases to around $40 \%$ at $350 \mathrm{~cm}$, before it drops to negligible values at the 


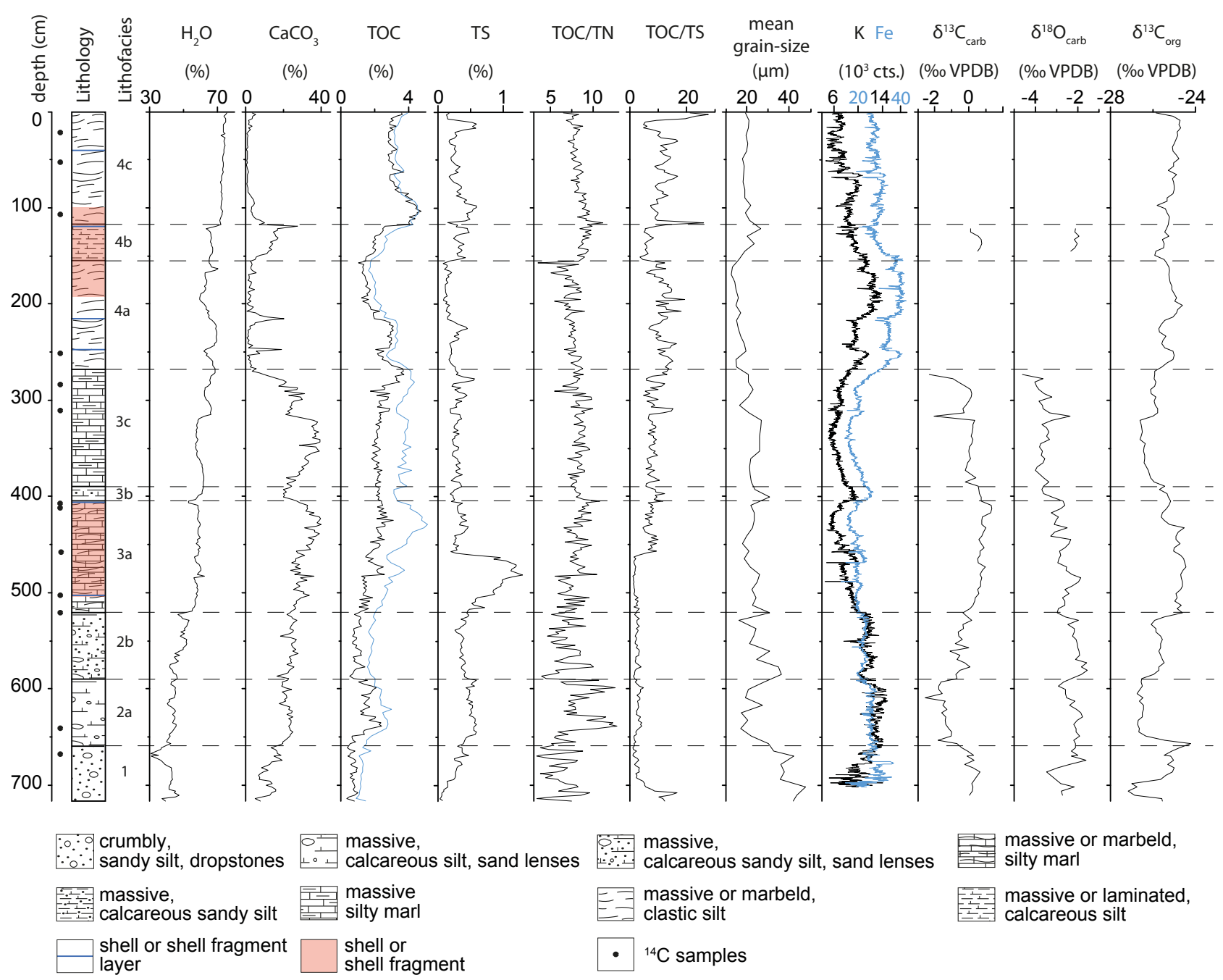

Fig. 3. Positions of ${ }^{14} \mathrm{C}$ samples (black dots), lithology, lithofacies, water content, calcite $\left(\mathrm{CaCO}_{3}\right)$, TOC (black line) and CaCO $\mathrm{Tadjusted}_{3}$ TOC (blue line), TS, TOC/N, TOC/TS, mean grain-size, Potassium (K, black line) and Iron (Fe, blue line) counts, $\delta^{13} \mathrm{C}_{\mathrm{carb}}, \delta^{18} \mathrm{O}_{\mathrm{carb}}$ and $\delta^{13} \mathrm{C}_{\text {org }}$ of core Co1260.

top. Although the $\mathrm{CaCO}_{3}$ content is similar to lithofacies $3 \mathrm{a}$, shell and shell fragments are absent. The decrease of $\mathrm{CaCO}_{3}$ at the top of this sub-lithofacies correlates with increasing $\mathrm{K}$ and $\mathrm{Fe}$ counts and a decrease of the mean grain-size from ca. $310 \mathrm{~cm}$. The change in sedimentary characteristics in lithofacies 3 are also reflected in the hydro-acoustic data, as reflector $3(4.46 \mathrm{~m})$ corresponds with the upper limit of the TS peak, and reflectors $4(4.00 \mathrm{~m})$ and $5(3.57 \mathrm{~m})$ represent distinct change in mean grain size (Fig. 3).

Lithofacies $4(265$ to $0 \mathrm{~cm})$ is dark olive brown to dark olive black, has a water content of 60 to $76 \%$ and a massive, marbled, or laminated structure. Medium and coarse silt dominate the grain-size composition. A high abundance of shell fragments and some well-preserved Dreissena bivalves occur between 195 and $100 \mathrm{~cm} . \mathrm{CaCO}_{3}$ is in general low, but shows some distinct peaks, where shells or shell fragments occur (Fig. 3). The occurrence of these shell layers seems to be irregular, as a layer of well-preserved Dreis sena bivalves was found at $32 \mathrm{~cm}$ in one core segment, but did not occur in the overlapping segment. Variations in sediment structure, colour, associated $\mathrm{CaCO}_{3}$ and $\mathrm{OM}$ allow a sub-division of lithofacies 4 . Lithofacies 4 a occurs between 265 and $152 \mathrm{~cm}$, is characterised by a massive or marbled structure, a dark olive brown colour, a low $\mathrm{CaCO}_{3}$, and decreasing trends in TOC content and TOC/TN. The mean grain size is the lowest for the entire sequence, whereas $\mathrm{K}$ and $\mathrm{Fe}$ reach maximum counts. This suggests pelagic sedimentation and a low productivity, or dilution by relatively high clastic input. Low productivity is confirmed by low TS and high TOC/TS, implying good mixing of the water column and potentially additional decomposition of OM. $\mathrm{CaCO}_{3}$ dissolution can be excluded, as ostracodes are well preserved. Lithofacies $4 \mathrm{~b}$, from 152 to $116 \mathrm{~cm}$, is massive or irregularly laminated, has a dark olive grey to very dark 


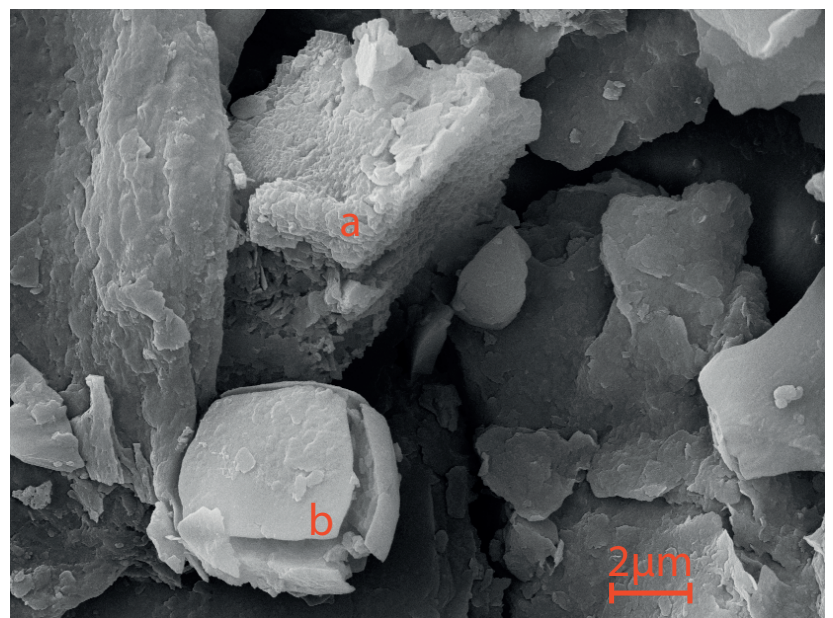

Fig. 4. SEM photos of bulk sediment from $137 \mathrm{~cm}$ depth in core Co1260 showing endogenic calcite $\left(\mathrm{CaCO}_{3}, \mathbf{a}\right)$ and pyrite $\left(\mathrm{FeS}_{2}\right.$, b). The broken structure of the pyrite is probably due to sample pre-treatment and heating to $50^{\circ} \mathrm{C}$.

brown colour, a relatively high $\mathrm{CaCO}_{3}$, TS and TOC/TN, mean grain size and a relatively low TOC/TS. TOC increases throughout lithofacies $4 \mathrm{~b}$. Lithofacies $4 \mathrm{c}$ comprises the uppermost $116 \mathrm{~cm}$ of core Co1262 and is massive, with a dark olive brown colour. Some faint black laminations occur between 18 and $8 \mathrm{~cm}$, where a peak in TS occurs. While $\mathrm{CaCO}_{3}$ is negligible, TOC is the highest of the entire core. The mean grain size is constant around $20 \mu \mathrm{m}$, but $\mathrm{K}$ and $\mathrm{Fe}$ counts show some distinct fluctuations in the uppermost ca. $60 \mathrm{~cm}$. Distinct change in sedimentological characteristics of lithofacies 4 can be correlated with the reflectors in the hydroacoustic profile (Fig. 2). Reflector $6(2.25 \mathrm{~m})$ coincides with a broad maximum in TOC and water content, reflector 7 $(1.92 \mathrm{~m})$ is, where the maximum in $\mathrm{K}$ and $\mathrm{Fe}$ counts can be observed and reflector $8(1.3 \mathrm{~m})$ marks the maximum in mean grain size and $\mathrm{CaCO}_{3}$.

The overall massive to marbled structure of the entire sediment succession suggests bioturbation. This is confirmed by a relatively high abundance ostracodes in the sediments. The occurrence of the ostracode Darwinula stevensoni (determined F. Viehberg), which was observed in sandy groundwater-influenced sediments (Meisch, 2000), substantiates that Lake Dojran is influenced by an aquifer.

\subsection{Isotope record}

$\delta^{18} \mathrm{O}_{\text {water }}$ and $\delta \mathrm{D}_{\text {water }}$ of samples from springs, which enter Lake Dojran, plot close to the global meteoric water line (GMWL, Fig. 5, Table 1). $\delta^{18} \mathrm{O}_{\text {water }}$ and $\delta \mathrm{D}_{\text {water }}$ of modern lake water have higher values and plot on a local evaporation line (LEL). The isotope data also show that the evaporation of the lake water was lower in 2011 compared to 1997 (cf. Griffiths et al., 2002), which corresponds with an increasing lakelevel in the last few years. Because the present lake level of Lake Dojran is below the outlet, the data also imply that aquifers play an important role in the water balance. Similarly to the water isotopes $(\mathrm{O}, \mathrm{D}), \delta^{13} \mathrm{C}_{\mathrm{TDIC}}$ of total dissolved inorganic carbon (TDIC) in the lake has higher values than the marginal springs (Table 1), most likely due a long residence time enabling the dissolved bicarbonates to exchange with isotopically heavier atmospheric $\mathrm{CO}_{2}$. This is a common feature in lakes, in which the water isotope geochemistry is dominated by evaporation (Leng and Marshall, 2004; Leng et al., 2012).

In core Co1260, the sediments from lithofacies 1 and 4 with TIC $<1 \%$ could not be analysed for carbon isotopic composition (Fig. 3). The rest of core Co1260 shows moderate fluctuations in $\delta^{18} \mathrm{O}_{\text {carb }}$ between -4.6 and $-1.2 \%$. These moderate values with relatively low variability (ca. 3\%o) suggest that the lake has not experienced complete hydrologic closure during the deposition of these sequences (cf. Roberts et al., 2008). Variations in $\delta^{18} \mathrm{O}_{\text {carb }}$ can be caused by changes in the isotopic composition of precipitation (linked to source and/or temperature variation), in the precipitation/evaporation $(P / E)$ ratio, or in the lake water residence time (cf. Roberts et al., 2008; Leng et al., 2012). $\delta^{13} \mathrm{C}_{\text {carb }}$ varies between -3.2 and $+1.4 \%$, with the lowest values in lithofacies $2 \mathrm{a}$ and at the top of lithofacies $3 \mathrm{c}$. These low values are probably due the greater contribution of soil derived $\mathrm{CO}_{2}$ or decomposition of $\mathrm{OM}$ relative to the amount of carbon from the carst and the atmosphere (cf. Leng et al., 2010).

The pattern of $\delta^{13} \mathrm{C}_{\text {org }}$, with values between -27.1 to $-24.2 \%$, corresponds only partly with $\delta^{13} \mathrm{C}_{\text {carb. Therefore, }}$. TDIC cannot be the only carbon pool for OM in the Lake Dojran sediments, which suggests that variations in $\delta^{13} \mathrm{C}_{\mathrm{org}}$ could also derive from change in allochthonous versus autochthonous OM deposition.

\subsection{Chronology}

The age model for core Co1260 is based on 13 radiocarbon ages and cross correlation with other lacustrine sediment cores from the Balkan region (Table 2, Fig. 6).

Seven samples, composed of terrestrial plant material and charcoal, provide a robust basis for the age model. However, there is an age reversal in samples COL $1320.1 .1(460.9 \mathrm{~cm}, 10820 \pm 420 \mathrm{cal} \mathrm{yr} \mathrm{BP})$ and COL 1321.1.1 (521.9 cm, $10660 \pm 440 \mathrm{cal} \mathrm{yr} \mathrm{BP,} \mathrm{Table} \mathrm{2).}$ Both samples are of terrestrial plant material and originate from the same core section, but sample COL 1320.1.1 was probably dislocated during opening of the cores, as it was found on the surface of the core halves. In contrast, sample COL 1321.1.1 was from the inner part of one of the core halves and is, therefore, considered to provide the accurate age.

In addition to the terrestrial plant samples, 2 bulk organic carbon and 3 carbonate samples were used for the establishment of the age-depth model. Bulk organic carbon, 
Table 1. Modern isotope data of spring and lake water as standard deviations from VSMOW (O, H isotopes) and VPDB (TDIC), collected in June 2011 (own data) and in September 1997 (Griffiths et al., 2002).

\begin{tabular}{lllrr}
\hline location & collection & $\begin{array}{l}\delta^{18} \mathrm{O}_{\text {water }} \\
(\% \text { VSMOW })\end{array}$ & $\begin{array}{r}\delta \mathrm{D}_{\text {water }} \\
(\% \text { VSMOW })\end{array}$ & $\begin{array}{r}\delta^{13} \mathrm{C}_{\text {TDIC }} \\
(\% \text { VPDB })\end{array}$ \\
\hline spring & June 2011 & -9.51 & -62.8 & -11.6 \\
spring & June 2011 & -8.08 & -50.5 & -13.0 \\
lake center & June 2011 & -0.91 & -13.0 & -5.9 \\
lake margin & June 2011 & -0.86 & -13.3 & -4.7 \\
lake margin & June 2011 & -0.86 & -13.1 & -4.8 \\
spring & September 1997 & -7.9 & -50.4 & -7.9 \\
lake center & September 1997 & +2.0 & +1.1 & +0.2 \\
lake margin & September 1997 & +2.1 & +1.9 & +0.6 \\
\hline
\end{tabular}

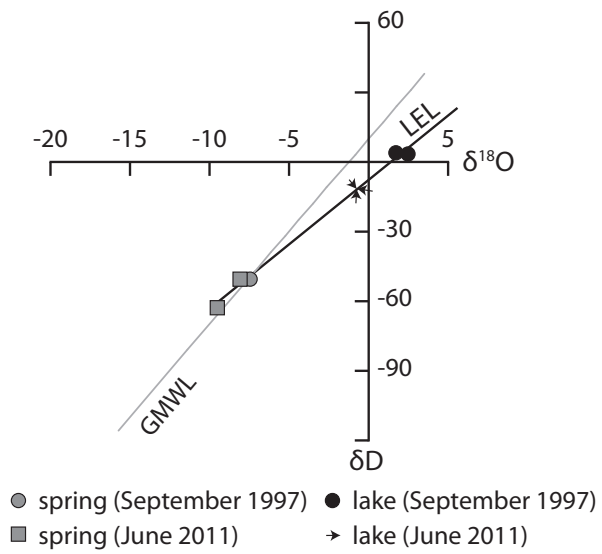

Fig. 5. The modern isotope composition $\left(\delta^{18} \mathrm{O}_{\text {water }}\right.$ and $\left.\delta \mathrm{D}_{\text {water }}\right)$ from water of Lake Dojran and from marginal springs. The samples were collected in September 1997 (Griffiths et al., 2002) and in June 2011 (see also Table 1). Arrows mark the lake water samples from June 2011 because they plot very close to each other in the $x$ $y$ plot. The lake water samples fall away from the Global Meteoric Water Line (GMWL) and plot on a Local Evaporation Line (LEL).

carbonate and terrestrial plant material samples can be influenced by reservoir effects, i.e., incorporation of fossil/old organic matter from bedrocks or other sources not in equilibrium with atmospheric ${ }^{14} \mathrm{CO}_{2}$ (Cohen, 2003 and references therein; Ramsey, 2008 and references therein). Terrestrial plant material in general is regarded to provide most reliable ages, as it is not or only marginally affected by the incorporation of aquatic carbon. However, in the record from Tenaghi Philippon pollen grains and peat indicated a significant reservoir effect (Pross et al., 2009). Bulk organic carbon and carbonate shell samples are more influenced by reservoir effects and have to be regarded more critically, particularly because reservoir effects can vary over time. This was also shown in the records from lakes Prespa and Ohrid (Vogel et al., 2010b; Aufgebauer et al., 2012). A low reservoir effect is suggested by the small age difference of COL 1312.1.1 (bulk organic carbon: $140 \pm 140$ cal yr BP) at $16.5 \mathrm{~cm}$ depth, a terrestrial plant residue from $53.3 \mathrm{~cm}$ (COL 1324.1.1: $410 \pm 110 \mathrm{cal}$ yr BP), and the sediment surface. Samples from $502.9 \mathrm{~cm}$ (ETH 449571.1, carbonate: $11250 \pm 60 \mathrm{cal} \mathrm{yr} \mathrm{BP)}$ ) and $521.9 \mathrm{~cm}$ depth (COL 1321.1.1, terrestrial plant: $10660 \pm 440$ cal yr BP) suggest a reservoir effect of several hundred years. The large difference between bulk organic $\mathrm{C}$ and carbonate ages at 635 and $682 \mathrm{~cm}$ depth (ETH 46615.1.1: $11920 \pm 310 \mathrm{cal}$ yr BP and ETH 44958.1.1: $32830 \pm 650 \mathrm{cal}$ yr BP) could indicate an even higher reservoir effect. On the other hand, a high TOC/TN of sample ETH 46615.1.1 indicates a predominantly terrestrial origin and suggest that the age of this sample could be reliable and that sample ETH 44958.1.1 is probably re-deposited. Redeposition can also be assumed for the shell fragment sample at $404.9 \mathrm{~cm}($ ETH $44956.1 .1 ; 7350 \pm 80 \mathrm{cal} \mathrm{yr} \mathrm{BP})$. This sample is significantly younger than the $2 \mathrm{~cm}$ underlying terrestrial plant fragment COL 1319.1.1 (8960 \pm 440 cal yr BP $)$ and there was no lithological indication for a hiatus or a distinct change in sedimentation rates. However, the age of sample COL 1319.1.1 is also somewhat questionable, as this sample has a very low carbon weight $(0.28 \mathrm{mg})$, and the calendar age is located on a ${ }^{14} \mathrm{C}$ plateau. A small reservoir effect can also not be excluded, as a minimum in $\mathrm{CaCO}_{3}$ at $397 \mathrm{~cm}$ depth in core Co1260 likely corresponds with the 8.2 ka cooling event, such as observed in nearby lakes Prespa and Ohrid (Wagner et al., 2009, 2010; Vogel et al., 2010a; Aufgebauer et al., 2012).

For the polynomial interpolation of the age depth model of core Co1260, the sediment surface was adjusted to -61.5 cal yr BP and 6 terrestrial plant material samples, the charcoal sample, the two bulk organic carbon samples, and the cross-correlation point at the $8.2 \mathrm{ka}$ cooling event were included (Table 2, Fig. 6). The calculated age model of core Co1260 yields a basal age of ca. 12500 cal yr BP. According to the established age model, the sedimentation rate of core Co1260 is high at the bottom and the top of the core and low between 390 and $330 \mathrm{~cm}$ sediment depth (Fig. 6). 
Table 2. Radiocarbon and calendar ages from core Co1260. The calibration of radiocarbon ages into calendar ages is based on Calib 6.1.1 (Stuiver and Reimer, 1993) and INTCAL09 (Reimer et al., 2009) and on a $2 \sigma$ uncertainty.

\begin{tabular}{lrlcll}
\hline AMS Lab ID & $\begin{array}{r}\text { core depth } \\
(\mathrm{cm})\end{array}$ & material & $\begin{array}{c}\text { C weight } \\
(\mathrm{mg})\end{array}$ & $\begin{array}{l}{ }^{14} \mathrm{C} \text { age } \\
(\mathrm{yr} \mathrm{BP})\end{array}$ & $\begin{array}{l}\text { calendar age } \\
(\text { cal yr BP })\end{array}$ \\
\hline COL 1312.1.1 & 16.5 & bulk organic C & 0.44 & $140 \pm 35$ & $140 \pm 140$ \\
COL 1324.1.1 & 53.3 & terrestrial plant & 0.45 & $360 \pm 70$ & $410 \pm 110$ \\
COL 1314.1.1 & 111.3 & terrestrial plant & 0.32 & $840 \pm 70$ & $790 \pm 120$ \\
COL 1194.1.1 & 253.0 & terrestrial plant & 1.00 & $2430 \pm 30$ & $2520 \pm 170$ \\
COL 1316.1.1 & 287.3 & terrestrial plant & 1.00 & $3080 \pm 30$ & $3290 \pm 80$ \\
COL 1317.1.1 & 309.1 & charcoal & 1.00 & $3560 \pm 40$ & $3850 \pm 130$ \\
ETH 44956.1.1 & 404.9 & carbonate & 1.01 & $6410 \pm 40$ & $7350 \pm 80$ \\
COL 1319.1.1 & 406.4 & terrestrial plant & 0.28 & $8020 \pm 150$ & $8960 \pm 440$ \\
COL 1320.1.1 & 460.9 & terrestrial plant & 0.63 & $9520 \pm 160$ & $10820 \pm 420$ \\
ETH 44957.1.1 & 502.9 & carbonate & 1.00 & $9840 \pm 40$ & $11250 \pm 60$ \\
COL 1321.1.1 & 521.9 & terrestrial plant & 0.90 & $9330 \pm 160$ & $10660 \pm 440$ \\
ETH 46615.1.1 & 635.0 & bulk organic C & 1.00 & $10220 \pm 70$ & $11920 \pm 310$ \\
ETH 44958.1.1 & 682.0 & carbonate & 0.48 & $28570 \pm 170$ & $32830 \pm 650$ \\
\hline
\end{tabular}

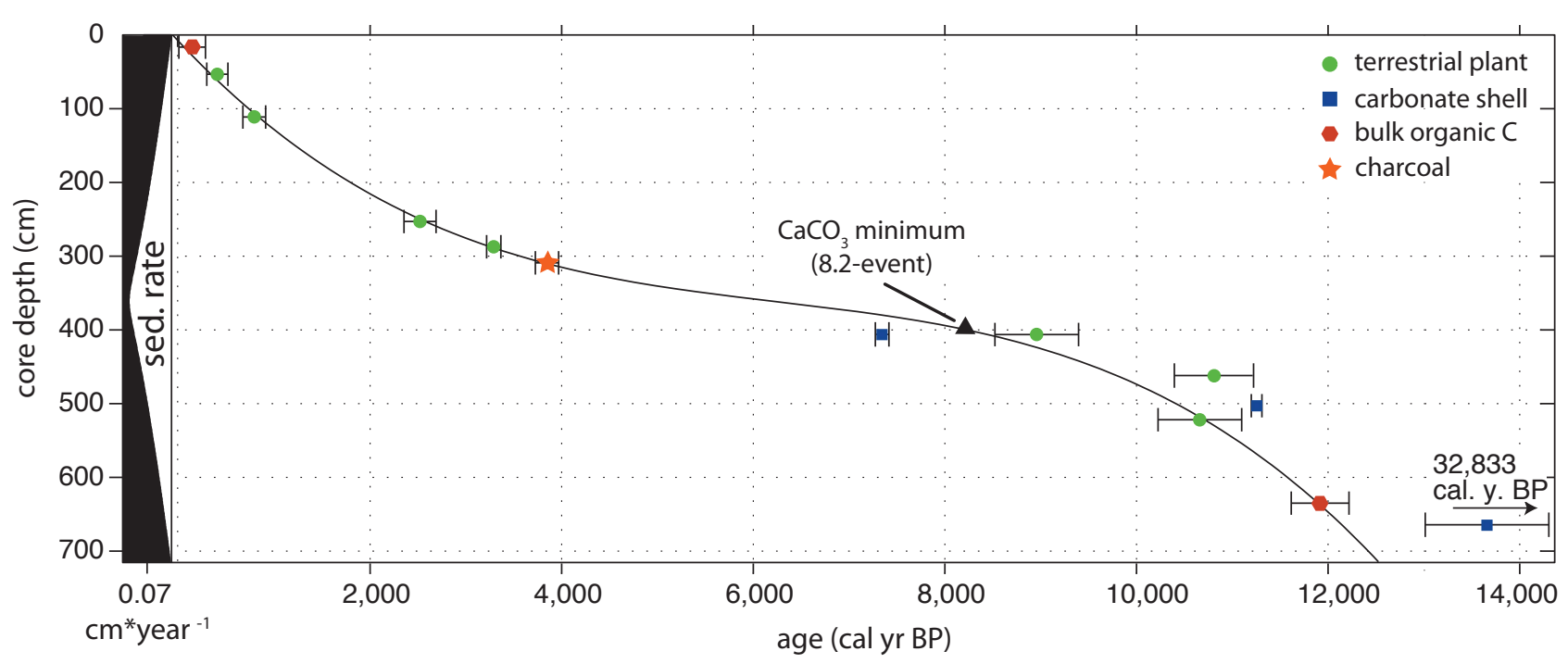

Fig. 6. Age-depth model of core Co1260 based on 13 calibrated radiocarbon ages derived from terrestrial plant material, charcoal, carbonates and bulk organic C samples. Additionally, the 8.2 ka cooling event described from lakes Ohrid and Prespa (Wagner et al., 2009, 2010; Vogel et al., 2010a; Aufgebauer et al., 2012) was correlated with the minimum in $\mathrm{CaCO}_{3}$ at $397 \mathrm{~cm}$ depth (see Fig. 3). Sample ETH 44958.1.1 from $682.0 \mathrm{~cm}$ depth, which has an age of $32830 \pm 650 \mathrm{cal}$ yr BP, was most likely re-deposited. The sedimentation rate was calculated from the polynomial age-depth model.

\section{Interpretation}

\subsection{Late Glacial (12500 to 11500 cal yr BP)}

The Late Glacial part of core Co1260 is represented by deposits of lithofacies 1 and $2 \mathrm{a}(717-590 \mathrm{~cm})$ and covers the period between 12500 and $11500 \mathrm{cal} \mathrm{yr} \mathrm{BP} \mathrm{(Figs.} 3$ and 7).

The deposits of lithofacies 1 between 717 and $658 \mathrm{~cm}$ represent the period 12500 to $12100 \mathrm{cal}$ yr BP. The high abundance of clay clasts, which are most likely formed under subaerial conditions, implies that the deposits were formed to a certain amount from redeposited lacustrine material.
This is confirmed by the undulated morphology of reflector 1 , which corresponds to the lower $17 \mathrm{~cm}$ of lithofacies 1 , and by the occurrence of the shell fragment with an age of $32830 \pm 650 \mathrm{cal}$ yr BP at $682 \mathrm{~cm}$ depth. Low lake level, redeposition, and intensive wave action are also indicated by a high mean grain-size and the overall poor sorting. The poor sorting is enhanced by the occurrence of drop stones from ice floe transport. As drop stones do not occur in the surface sediments of Lake Dojran and the modern lake is only occasionally covered by ice (Zacharias et al., 2002), winter temperatures during the deposition of lithofacies 1 must have been lower than today. Lower temperatures are also 


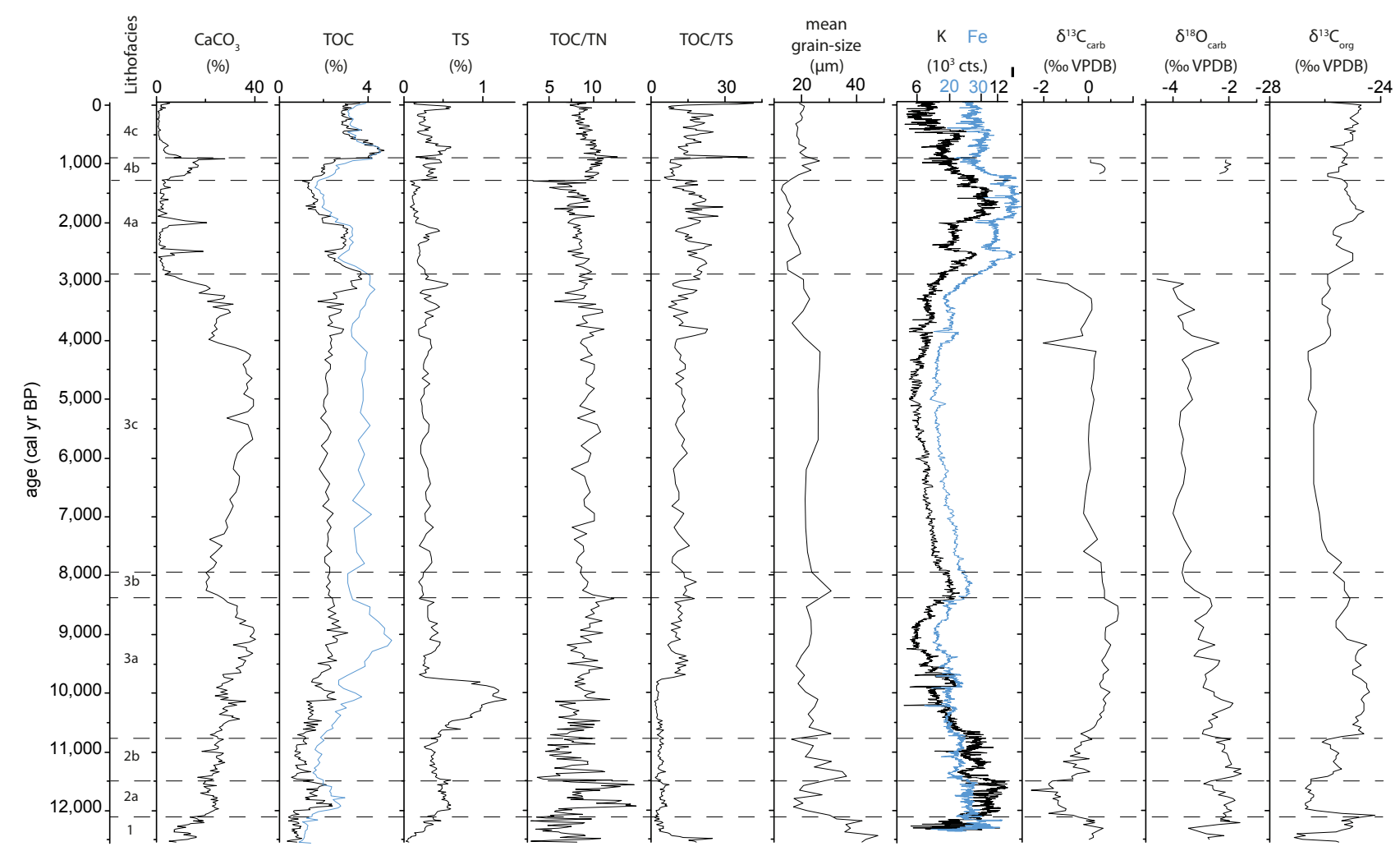

Fig. 7. Lithofacies, calcite $\left(\mathrm{CaCO}_{3}\right)$, TOC (black line) and $\mathrm{CaCO}_{3}$ adjusted TOC (blue line), TS, TOC/N, TOC/TS, mean grain-size, Potassium (K, black line) and Iron (Fe, blue line) counts, $\delta^{13} \mathrm{C}_{\text {carb }}, \delta^{18} \mathrm{O}_{\text {carb }}$, and $\delta^{13} \mathrm{C}_{\text {org }}$ of core Co1260 plotted versus age.

suggested by the relatively low $\mathrm{OM}$ and $\mathrm{CaCO}_{3}$. In the modern lake, low lake levels during relatively warm conditions correspond with periods of algal blooms and eutrophication (cf. Griffiths et al., 2002). Intensive macrophyte growth, such as often occurs during low lake levels (cf. Coops et al., 2003; Beklioglu et al., 2006), is also not evident in lithofacies 1 . However, there are some smaller fluctuations in $\mathrm{OM}$ and $\mathrm{CaCO}_{3}$, which indicate minor variations in local temperatures or lake level. A minimum of $\delta^{13} \mathrm{C}_{\mathrm{org}}$ and a maximum in TOC/TN suggest increased allochthonous OM input at this time. A low lake level could have promoted the degradation of OM, particularly in the lowermost $17 \mathrm{~cm}$ of lithofacies 1, where a high TOC/TS indicates higher oxygen supply to the surfaces sediments. Relatively low $\delta^{18} \mathrm{O}_{\text {carb }}$ values until 12250 cal yr BP and subsequent higher values at the top of lithofacies 1 imply increased evaporation and correspond to a subtle finer grain-size distribution. A higher lake level could reduce the wave action at Co1260 and enlarge the surface area of the lake water, while the water volume would only increase marginally due to the flat-bottomed nature of Lake Dojran. Greater surface area promotes more evaporation of the lake water. Overall, the sedimentary characteristics imply cold and dry conditions between 12500 to $12100 \mathrm{cal}$ yr BP.

The deposits of lithofacies 2a from 658 to $590 \mathrm{~cm}$ depth represent the period 12100 to $11500 \mathrm{cal} \mathrm{yr} \mathrm{BP.} \mathrm{The}$ environmental conditions during this period are difficult to disentangle. The absence of clay clasts and a lower mean grain size imply less re-deposition, low wave action, and a higher lake level. A slightly higher lake level is confirmed by the onlap structures of reflector 2 (Fig. 2). Fine sand lenses, which are interpreted as IRD, indicate that the lake was still ice covered during winter. A relatively high sediment supply, probably from increased inflow by rivers or creeks, is indicated by increased $\mathrm{K}$ and $\mathrm{Fe}$ counts between 12100 and $11500 \mathrm{cal} \mathrm{yr} \mathrm{BP}$. Enhanced erosion and input of soil derived $\mathrm{CO}_{2}$ is also suggested by low $\delta^{13} \mathrm{C}_{\mathrm{carb}}$, as a low TOC/TS suggests that oxidation of $\mathrm{OM}$ was negligible. Higher $\mathrm{OM}$ and $\mathrm{CaCO}_{3}$ content during this period indicate enhanced productivity and slightly higher summer temperatures and more humid conditions. Unstable environmental conditions between 12100 and $11500 \mathrm{cal} \mathrm{yr} \mathrm{BP}$ are indicated by two maxima in $\mathrm{OM}$ and TOC/TN and slight minima in $\delta^{13} \mathrm{C}_{\mathrm{org}}$ at 11900 and $11560 \mathrm{cal}$ yr BP, which are probably caused by increased allochthonous nutrient supply. The interspersed minimum in OM between 11800 and 11600 cal yr BP corresponds to low TOC/TN and implies a short period of less allochthonous nutrient supply and reduced water inflow from rivers or creeks. The $\delta^{18} \mathrm{O}_{\text {carb }}$ decrease between 11800 and 11500 cal yr BP probably corresponds with an isotopic depletion at the end of the Younger Dryas, which is described 
from various lacustrine isotope records from the Mediterranean region and indicates increasing humidity (Roberts et al., 2008 and references therein).

Overall cold and dry climate between 12500 and $11500 \mathrm{cal}$ yr BP at Lake Dojran can be attributed to the Younger Dryas, when $6{ }^{\circ} \mathrm{C}$ lower temperatures and arid conditions with $50 \%$ less annual precipitation compared to modern conditions are reported from the northern Aegean region (Kotthoff et al., 2008a, 2011), the Sea of Marmara (Valsecchi et al., 2012), and from other terrestrial records in Italy (Allen et al., 2002), Macedonia (Bordon et al., 2009; Panagiotopoulos et al., 2012), and Greece (Digerfeldt et al., 2000; Lawson et al., 2004). However, the cold and dry climate during the Younger Dryas is barely visible in geochemical and hydrological data from lakes Prespa and Ohrid (Fig. 8). This is probably due to the long lake water residence time in Ohrid (Leng et al., 2012) and lower winter temperatures and moisture deficits, which have only minor effects on lake internal processes (Vogel et al., 2010a; Aufgebauer et al., 2012; Panagiotopoulos et al., 2012). Lake Dojran with its low volume to large surface area is likely more sensitive to hydrological change. The transition from a low lake level and low temperatures during the formation of lithofacies 1 towards higher a lake level and warmer temperatures during the sedimentation of lithofacies $2 \mathrm{a}$ at Lake Dojran around $12100 \mathrm{cal}$ yr BP corresponds well with marine records from the western Mediterranean Sea and the North Atlantic, and with terrestrial archives from the Iberian Peninsula and northwest Europe (Cacho et al., 2001 and references therein). Furthermore, the transition might correspond to a decrease in salinity in the Levantine Basin and the Ionian Sea after 12000 cal yr BP (cf. Emeis et al., 2000). However, a separation in two phases such as indicated by Co1260 is not evident in other terrestrial records from Greece or in marine pollen records from the Aegean Sea and the Sea of Marmara (Rossignol-Strick, 1993; Digerfeldt et al., 2000; Lawson et al., 2004, 2005; Kotthoff et al., 2008a, 2011; Valsecchi et al., 2012). At least the particular dry phase described from the northern Aegean region around $11800 \mathrm{cal} \mathrm{yr} \mathrm{BP}$ (Kotthoff et al., 2008a, 2011) corresponds with the low OM content and low TOC/TN ratios in Co1260 between 11800 and 11600 cal yr BP.

\subsection{Early Holocene (11 500 to 7900 cal yr BP)}

The deposits of lithofacies $2 \mathrm{~b}, 3 \mathrm{a}$ and $3 \mathrm{~b}(590-390 \mathrm{~cm})$ in core Co1260 represent the early Holocene between 11500 and 7900 cal yr BP (Figs. 3 and 7).

Lithofacies $2 \mathrm{~b}(590-520 \mathrm{~cm})$ covers the period 11500 to $10700 \mathrm{cal}$ yr BP. The sporadic occurrence of sand lenses indicates that the winter temperatures at Lake Dojran remained low. Low winter temperatures during the early Holocene are also reported from Lake Ohrid and are explained by southward movement of cold polar air during winter seasons (Vogel et al., 2010a; Wagner et al., 2010).
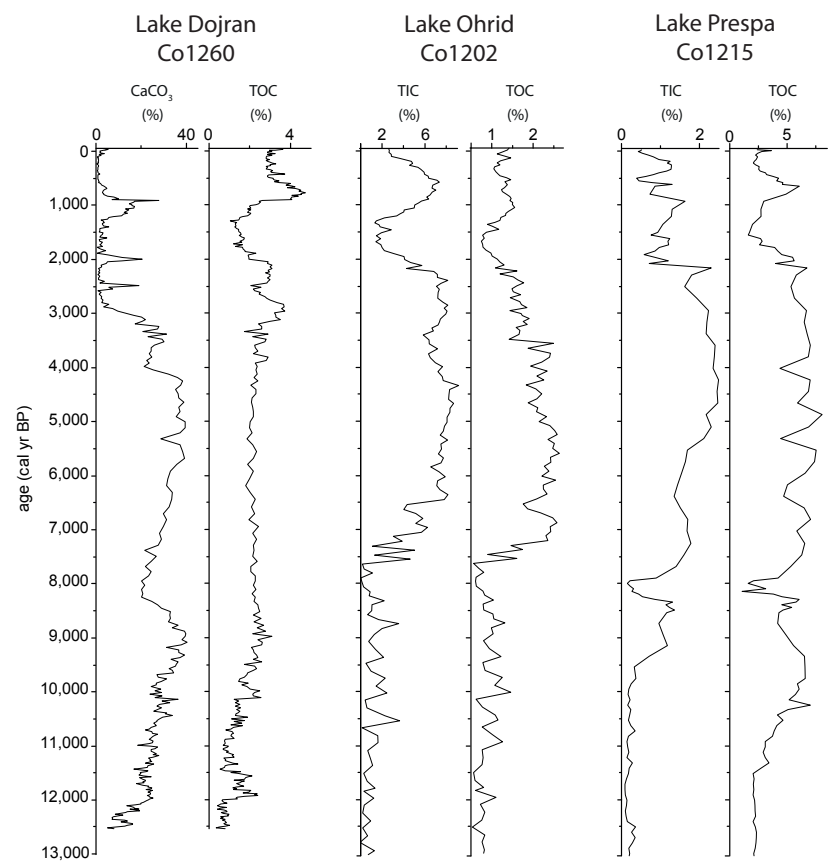

Fig. 8. $\mathrm{CaCO}_{3}$ and TOC of core Co1260 from Lake Dojran in comparison to $\mathrm{CaCO}_{3}$ and TOC content from lakes Ohrid (Vogel et al., 2010a) and Prespa (Aufgebauer et al., 2012) during the last 13000 cal yr BP.

Although the occurrence of the sand lenses leads to distinct variations in grain-size distribution, the overall coarser sediments suggest relatively high transport energy at coring location Co1260. The high transport energy is most likely due to stronger inflow and not triggered by a lake-level low stand, because clay clasts are absent and there is no indication for a very low lake level in the hydro-acoustic profile (Fig. 2). A constant $\mathrm{CaCO}_{3}$ along with lower allochthonous clastic and organic sediment input, indicated by lower $\mathrm{K}, \mathrm{Fe}$, TOC/TN, and higher $\delta^{13} \mathrm{C}_{\text {org }}$, implies somewhat lower productivity in the lake, which corresponds with lower TOC. Thereby, the higher $\delta^{13} \mathrm{C}_{\text {org }}$ are probably rather a result of less allochthonous OM than of more productivity. The discrepancy between relatively high inflow and low erosion can be explained by the development of a dense vegetation cover in the catchment, such as observed around lakes Prespa and Maliq to the west (Bordon et al., 2009; Aufgebauer et al., 2012; Panagiotopoulos et al., 2012) and the Aegean region to the south and southeast (Kotthoff et al., 2008a). Extensive reed beds in the littoral areas of Lake Dojran could have also restrained allochthonous clastic supply by filtering and organic sediment supply by nutrient consumption (cf. Yin and Lan, 1995; Wang et al., 2002). This could have limited the productivity in the lake center although temperatures increased rapidly in the Mediterranean region during the early Holocene (Allen et al., 1999; Bordon et al., 2009; Kotthoff et al., 2011). Despite more humid conditions as 
indicated by our data, the low TOC/TS implies oxygen depletion in the bottom waters and stratification of the lake during summer. Summer stratification was probably promoted by higher summer temperatures in the early Holocene, such as reported from various records in the central and eastern Mediterranean region (e.g., Allen et al., 1999; Lawson et al., 2004; Kotthoff et al., 2008a; Vogel et al., 2010a; Peyron et al., 2011; Aufgebauer et al., 2012). Increased humidity in the early Holocene conflicts with the high $\delta^{18} \mathrm{O}_{\text {carb }}$ values, which would normally be interpreted as indicating a low $P / E$ ratio. Enhanced evaporation, however, is enabled by a higher lake level when this is accompanied by an increasing lake water surface area especially in lakes like Dojran, which is located in a flat-bottomed basin (cf. Leng et al., 2005; Hernández et al., 2008). A large surface area also promotes greater exchange of TDIC with atmospheric $\mathrm{CO}_{2}$ and, therefore, tends to lead to both higher $\delta^{13} \mathrm{C}_{\mathrm{TDIC}}$ and $\delta^{13} \mathrm{C}_{\mathrm{carb}}$ as seen in lithofacies $2 b$.

In lithofacies 3a $(520-401 \mathrm{~cm})$, which covers the period 10700 to 8300 cal yr BP, the grain-size distribution is dominated by medium and coarse silt, but is less variable due to the lack of fine sand lenses. The lack of the sand lenses indicates that the lake was not significantly covered by ice during winter. The decreasing $\delta^{18} \mathrm{O}_{\text {carb }}$ after $10200 \mathrm{cal} \mathrm{yr} \mathrm{BP}$ could be associated with a greater through flow due to further increasing humidity. This corresponds with increasing moisture in southern Italy until 9400 cal yr BP (Joannin et al., 2012), but in particular with increasing $\delta^{18} \mathrm{O}_{\text {carb }}$ after 9400 cal yr BP at Lake Prespa, which was explained by increasing summer wetness (Leng et al., 2010). Despite this increasing humidity during the early Holocene, which incidentally coincides partly with the formation of sapropel $1 \mathrm{a}$ between ca. 10000 and $8200 \mathrm{cal} \mathrm{yr} \mathrm{BP}$ in the Mediterranean Sea (Emeis et al., 2000; Mercone et al., 2000; Kotthoff et al., 2008b; Schmiedl et al., 2010), K and Fe imply decreasing catchment erosion until 9000 cal yr BP. Less input from the catchment could be due to denser vegetation in the littoral areas and catchment, which while filtering clastic material might cause greater delivery of more allochthonous OM to the lake, as indicated by increasing TOC/TN. Another explanation for increasing allochthonous OM supply could be as a result of lake level increase and flooding of the shallow, reed bed-covered littoral parts of the lake. This is indicated by reflector 3 in the seismic data, which is the oldest reflector that covers the lacustrine terrace in the northern part of profile 2 (Fig. 2). The flooded shallow lake parts would have formed suitable habitats for Mollusca, which probably explains the high abundance of shells and shell fragments in lithofacies 3a. The increase in lake surface and volume was apparently correlated with a distinct change in redox conditions, such as indicated in the TS peak and the shift of TOC/TS. The larger surface could have led to higher wind fetch and, thus, a better mixing of the water column after $9500 \mathrm{cal}$ yr BP. More nutrient and allochthonous OM supply from the flooded parts likely promoted productivity in the lake, and can be inferred from a minimum of $\delta^{13} \mathrm{C}_{\mathrm{org}}$ and maxima in $\mathrm{CaCO}_{3}$ adjusted TOC and $\mathrm{CaCO}_{3}$ around 9000 cal yr BP. Decreasing $\mathrm{CaCO}_{3}$ and $\mathrm{CaCO}_{3}$ adjusted TOC contents after $8700 \mathrm{cal} \mathrm{yr} \mathrm{BP}$ suggests decreasing lake productivity, which goes along with increasing erosion, such as indicated by increasing $\mathrm{K}$ and $\mathrm{Fe}$.

In lithofacies $3 \mathrm{~b}$ from 401 to $390 \mathrm{~cm}$, which covers the period 8300 to $7900 \mathrm{cal} \mathrm{yr} \mathrm{BP}$, the coarser grain-size distribution implies relatively high transport energy. Increased transport energy is probably due to a lower lake level and increased wave action, which is indicated by the pinching out of the hydro-acoustic reflector 4 in the central area of the lake. A low lake level implies dry conditions at Lake Dojran, which is, however, inconsistent with low $\delta^{18} \mathrm{O}_{\text {carb. }}$ Potential explanations for the lower $\delta^{18} \mathrm{O}_{\text {carb }}$ are a smaller surface area, which reduces evaporation, or increasingly lower $\delta^{18} \mathrm{O}$ of rainfall from the Atlantic (Zanchetta et al., 2007a) or eastern Mediterranean origin (cf. Develle et al., 2010). Despite the presumed arid conditions, high $\mathrm{K}$ and Fe imply enhanced clastic sediment supply and erosion in the catchment, which is probably associated with a less dense vegetation cover in the catchment. Less dense vegetation could have reduced the availability and supply of allochthonous $\mathrm{OM}$ to the lake as suggested by low TOC/TN and high $\delta^{13} \mathrm{C}_{\text {org }}$, and could also be triggered by lower temperatures. This is also suggested by subtly lower TS and higher TOC/TS, indicating less pronounced thermal stratification and improved oxygen supply to the surface sediments. Furthermore, low $\mathrm{CaCO}_{3}$ and $\mathrm{CaCO}_{3}$ adjusted TOC contents in lithofacies $3 \mathrm{~b}$ imply low productivity, such as also reported from lakes Prespa and Ohrid (Wagner et al., 2009, 2010; Vogel et al., 2010a; Aufgebauer et al., 2012). The low temperatures are most likely associated with the $8.2 \mathrm{ka}$ cooling event, which covers a broad period in Mediterranean paleoclimate records varying between 8500 and 8000 cal yr BP (e.g., Magny et al., 2003 and references therein; Rohling and Palike, 2005; Berger and Guilaine, 2009 and references therein). The $8.2 \mathrm{ka}$ cooling is associated with an interruption of the sapropel 1 formation in the Mediterranean Sea (e.g., Kotthoff et al., 2008b; Schmiedl et al., 2010; Siani et al., 2012) and a hydrological tripartition of Europe. Whilst wet conditions have predominated between 43 to $50^{\circ} \mathrm{N}$, dry conditions persisted north and south of this corridor (Magny et al., 2003), which is in line with low lake level and dry conditions at Lake Dojran. Pollen analyses from Lake Maliq (Bordon et al., 2009) and Tenaghi Philippon (Peyron et al., 2011) suggest that the dryness is predominantly due to restricted winter precipitation.

\subsection{Mid-Holocene (7900 to 2800 cal yr BP)}

The deposits of lithofacies $3 \mathrm{c}$ from 390 to $265 \mathrm{~cm}$ of core Co1260 represent the mid-Holocene between 7900 and 2800 cal yr BP (Figs. 3 and 7).

The finer and relatively stable grain-size distribution at least until 4300 cal yr BP implies lower wave action, a high 
lake level, and humid conditions with only minor fluctuations and more inflow. A relatively high lake level between 7900 and 4300 cal yr BP is also suggested by reflector 5 $(3.57 \mathrm{~m}$, around $6000 \mathrm{cal}$ yr BP) in the hydro-acoustic data (Fig. 2). The onlap structures to reflector 3 in the lateral parts of the lake imply that the lake level did not exceed that of the early Holocene. A high lake level until around $6000 \mathrm{cal} \mathrm{yr} \mathrm{BP}$ could correlate with the formation of S1b (Emeis et al., 2000; Mercone et al., 2000; Kotthoff et al., 2008b; Schmiedl et al., 2010). The broad maxima in $\mathrm{CaCO}_{3}$ and mean grain-size between ca. 6000 and $4300 \mathrm{cal}$ yr BP correlates with a minimum in $\mathrm{K}$ and $\mathrm{Fe}$ and suggests slightly increased productivity, slightly reduced lake level and lower supply of clastic material. This is likely correlated to warmer temperatures and more arid conditions during the mid-Holocene, such as observed in other paleoclimate records in the Mediterranean region (e.g., Wick et al., 2003; Kotthoff et al., 2008a,b; Roberts et al., 2008; Wagner et al., 2009; Leng et al., 2010; Vogel et al., 2010a; Aufgebauer et al., 2012; Joannin et al., 2012). The shift from more humid to more arid conditions at Lake Dojran was only moderate, as OM, TS, TOC/TS, TOC/TN, $\delta^{13} \mathrm{C}_{\text {org }}$, and $\delta^{18} \mathrm{O}_{\text {carb }}$ in core Co1260 are relatively stable between 7900 and 4300 cal yr BP. In addition, the stable $\delta^{18} \mathrm{O}_{\text {carb }}$ during this period suggests that the atmospheric circulation pattern was relatively stable and that there was no distinct shift in the origin of rainfall. Low and stable $\delta^{18} \mathrm{O}_{\text {carb }}$ during the mid-Holocene is a common feature in central Mediterranean isotope lake sediment records, although there are some differences in the exact timing (e.g., Zanchetta et al., 2007b; Roberts et al., 2008; Develle et al., 2010; Leng et al., 2012 and references therein).

Between 4300 and $2800 \mathrm{cal}$ yr BP, more fluctuations and a distinct change in some of the proxies suggest greater instability during a period of gradual environmental change at Lake Dojran. A minimum in mean grain-size and a peak in $\delta^{18} \mathrm{O}_{\text {carb }}$ around $4000 \mathrm{cal}$ yr BP suggest low inflow, dry conditions and/or ${ }^{18} \mathrm{O}$ enriched rainfall for a short period. This period coincides with low lake productivity, as indicated by $\mathrm{CaCO}_{3}$ adjusted TOC and $\mathrm{CaCO}_{3}$. Low productivity is likely caused by low temperatures, as low TOC/TS imply less intensive thermal stratification. Restricted nutrient availability is less likely, as increasing $\mathrm{K}$ and Fe counts imply increasing clastic supply and erosion in the catchment. The short period of low temperatures and arid conditions around $4000 \mathrm{cal}$ yr BP is most likely associated with the $4.2 \mathrm{ka}$ cooling event, which has been described in other records from the Mediterranean region (e.g., Bar-Matthews et al., 1999; Weiss and Bradley, 2001; Magny et al., 2009; Wagner et al., 2009; Vogel et al., 2010a). The $4.2 \mathrm{ka}$ cooling event in the Mediterranean region corresponds to low lake levels in North Africa and the Near East, which is explained by a weak African monsoon (Kotthoff et al., 2008a and references therein; Magny et al., 2009). In addition, a positive NAO (North Atlantic Oscillation) index favours cold and dry conditions in the Mediterranean region by reduced moisture availability of Atlantic origin and cold polar air outbreaks from the Siberian high (Lamy et al., 2006; Magny et al., 2009). Subsequent to the $4.2 \mathrm{ka}$ cooling event, increasing $\mathrm{K}$ and $\mathrm{Fe}$ and a higher mean grain size imply higher erosion in the catchment, stronger inflow and more humid conditions. More humid conditions between 3950 and 3800 cal yr BP are also reported from the central and western Mediterranean regions (Magny et al., 2009). Erosion processes could also have been promoted by human induced deforestation, as pollen analyses indicate first permanent settlements at Lake Dojran during this period (Athanasiadis et al., 2000). The anthropogenic deforestation was probably intensified until ca. $2800 \mathrm{cal} \mathrm{yr} \mathrm{BP}$ as indicated by increasing $\mathrm{K}$ and $\mathrm{Fe}$ and decreasing $\delta^{13} \mathrm{C}_{\text {carb }}$, the latter one is a proxy for enhanced soil derived $\mathrm{CO}_{2}$ or enhanced remineralisation of $\mathrm{OM}$ in the lake. The enhanced clastic sedimentation coincides with decreasing $\mathrm{CaCO}_{3}$. Comparable human-induced modifications of the environmental setting and the sedimentological properties around the same time are also reported from Lake Prespa (Aufgebauer et al., 2012; Panagiotopoulos et al., 2012) and Lake Ohrid (Wagner et al., 2009; Vogel et al., 2010a, Fig. 8).

\subsection{Late Holocene (2800 cal yr BP to present)}

The deposits of lithofacies $4(265-0 \mathrm{~cm})$ in core Co1260 represent the late Holocene between $2800 \mathrm{cal}$ yr BP and today (Figs. 3 and 7).

In lithofacies $4 \mathrm{a}$ ( 265 to $152 \mathrm{~cm}$ ), which covers the period 2800 to $1200 \mathrm{cal}$ yr BP, the decreasing mean grain-size indicates declining inflow and a decreasing lake level. A decreasing lake level is also suggested by the hydro-acoustic data, where reflector $6(2.25 \mathrm{~m})$ occurs in lateral parts of the lake, whereas the overlaying reflector $7(1.92 \mathrm{~m})$ pinches out in these parts (Fig. 2). Relatively arid conditions in the Mediterranean region during the late Holocene are also reported from other records, including Lake Prespa (Schilman et al., 2001; Roberts et al., 2008 and references therein; Joannin et al., 2012; Leng et al., 2012; Siani et al., 2012). A lower lake level at Lake Dojran could have resulted in a relative enlargement of shallow lake areas covered by reed beds. The reed beds likely restricted the productivity in the lake (low TOC, $\mathrm{CaCO}_{3}$ and TS), as they retain the supply of allochthonous $\mathrm{OM}$ and nutrients (decreasing TOC/TN, high $\delta^{13} \mathrm{C}_{\mathrm{org}}$ ). The reed beds, however, did not lead to less supply of clastic material (high $\mathrm{K}, \mathrm{Fe}$ and sedimentation rates), probably because human-induced wood clearance and anthropogenic impact in the catchment increased (cf. Athanasiadis et al., 2000), as it is also reported from other records in the eastern and northeastern Mediterranean region (Willis, 1994; Denèfle et al., 2000; Kotthoff et al., 2008a; Bordon et al., 2009; Panagiotopoulos et al., 2012; Valsecchi et al., 2012). A lower lake level could also have promoted the occurrence of shells and shell redeposition (Bially and Macisaac, 2000) by greater exposure of the shell beds to wave action. This assumption is supported 
by high abundances of shells or shell fragments in upper parts of lithofacies 4a. The low lake level is also indicated in a distinct shift of sedimentation rates in a sediment core from the lateral parts of the lake (Athanasiadis et al., 2000). This shift is likely caused by a hiatus, when lateral parts of the lake became sub-aerially exposed. Despite the anthropogenic overprint, the period between 2800 to 1200 cal yr BP apparently was characterised by a slight cooling, which resulted in reduced thermal stratification as suggested by relatively high TOC/TS.

In lithofacies $4 \mathrm{~b}(152$ to $116 \mathrm{~cm})$, which covers the pe-

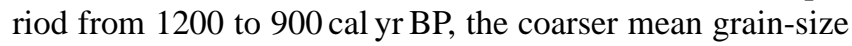
implies higher transport energy, which is probably associated with more inflow and humid conditions and a higher lake level. The higher lake level is also indicated by the occurrence of the hydro-acoustic reflector 8 in lateral parts of Lake Dojran. A lower proportion of reed likely covered the lateral parts of the lake leading to a reduced filter effect and enhanced supply of allochthonous OM, as seen in high TOC/TN and lower $\delta^{13} \mathrm{C}_{\text {org }}$. Flooding of reed-covered areas would have enlarged the surface area of the lake, which would again promote the exchange of TDIC with atmospheric $\mathrm{CO}_{2}$, such as suggested by the high $\delta^{13} \mathrm{C}_{\text {carb }}$. The enlarged surface area also intensified summer evaporation, as indicated by high $\delta^{18} \mathrm{O}_{\text {carb }}$. The gradual increase of $\mathrm{OM}$ and $\mathrm{CaCO}_{3}$ is likely due to higher lake productivity, and could be additionally caused by declining anthropogenic activities, less erosion and supply (dilution) of clastic material from the catchment. A similar observation was made at Lake Prespa and explained by a denser vegetation cover between 1500 and 600 cal yr BP (Aufgebauer et al., 2012). Lake productivity was likely promoted by a warmer climate associated with the Medieval Warm Period (cf. Crowley and Lowery, 2000), which resulted in an intensification of the thermal stratification during summer and in high TS, low TOC/TS and the faintly laminated structures in lithofacies $4 \mathrm{~b}$.

In lithofacies $4 \mathrm{c}(116$ to $0 \mathrm{~cm})$, which covers the period from 900 cal yr BP until today, the subtle finer grain-size distribution suggests lower transport energy, inflow and lake level. Significant lake level fluctuations, such as that reported from lakes Prespa and Ohrid (Matzinger et al., 2006; Wagner et al., 2009; Vogel et al., 2010a; Aufgebauer et al., 2012), are not recorded in Lake Dojran. We can assume that anthropogenic impact affected the lake hydrology and the catchment dynamics of Lake Dojran significantly during this period. Nevertheless, reduced precipitation of $\mathrm{CaCO}_{3}$ along with high OM implies high productivity, but low temperatures subsequent to the Medieval Warm Period. Low temperatures are also indicated by high TOC/TS in lithofacies $4 c$, which implies restricted thermal stratification during summer. The colder temperatures after the Medieval Warm Period are also observed in other records from the Balkan areas and are commonly attributed to the Little Ice Age (Wagner et al., 2009; Vogel et al., 2010a; Aufgebauer et al., 2012). The lake level lowstand of Lake Dojran about 2-3 decades ago, when the maximum water depths was $<4 \mathrm{~m}$, is not obvious in the sediment record. The only hint for the lake level lowstand could come from a sub-surface peak in TS. The lake level lowstand was likely caused by a combination of dry climate and by high water use for irrigation, which likely promoted the eutrophication, as shown by the increasing TOC and $\mathrm{CaCO}_{3}$ in the upper few centimetres of core $\mathrm{Co} 1260$ and confirmed by other surface sediment cores (Griffiths et al., 2002).

\section{Conclusions}

The investigation of the sediment architecture of Lake Dojran and sediment properties of core Co1260 provides valuable information on climate variability and human impact in the Balkan region. As Lake Dojran is a relatively shallow lake for its size, paleoclimatic change and human interactions seem to have had a significant impact on lake hydrology, allochthonous supply of OM and clastic material, and lake productivity. The shallow morphology of Lake Dojran causes greater evaporation of the lake water when lake levels are relatively high and supports that reed beds in littoral areas of the lake are apparently crucial for in-lake processes, as these reed beds consume nutrients from the catchment and reduce lake internal productivity. The following interpretations, based on analysis of the data presented here, for climate variability and human impact from the Lake Dojran sediment sequence can be drawn for the Late Glacial and Holocene:

Cold and dry conditions with low productivity and a low lake-level persisted between 12500 to $12100 \mathrm{cal}$ yr BP and are followed by slightly higher temperatures and more humid conditions with subtle enhanced productivity and a higher lake level until $11500 \mathrm{cal} y \mathrm{BP}$. This entire period is attributed to the Younger Dryas. Similarly to the western, contrasting findings from the eastern Mediterranean region and the northern high latitudes, the Younger Dryas can be separated into an early cold and dry early period followed by a warmer and more humid later period.

During the early Holocene (11500 to 8300 cal yr BP), temperatures increased, though nutrient availability and productivity in the lake were restricted until $10700 \mathrm{cal} \mathrm{yr} \mathrm{BP}$. This is likely due to the impact of filtering of the inflow through littoral reed beds. More humid conditions and higher lake level coincide with the formation of sapropel 1 (S1a) in the marine realm and improved the nutrient supply to the lake by more runoff and smaller reed beds. Highest productivity occurred around $9000 \mathrm{cal} \mathrm{yr} \mathrm{BP}$ and implies a thermal maximum in the region. Lake level lowering and lower productivity between 8300 and $7900 \mathrm{cal} \mathrm{yr} \mathrm{BP}$ implies a return to drier conditions and lower temperatures during the $8.2 \mathrm{ka}$ cooling event.

Stable conditions between 7900 and 4300 cal yr BP suggest that the more arid conditions after the formation of sapropel 1 (S1b) had only minor impact on hydrology and productivity of Lake Dojran. More unstable 
conditions and gradual environmental change occurred between 4300 and 2800 cal yr BP. Dry and cold conditions around $4000 \mathrm{cal}$ yr BP are correlated with the $4.2 \mathrm{ka}$ cooling event, whereas increasing erosion is most likely associated with human induced wood clearance of the catchment of Lake Dojran.

Intensive anthropogenic impact occurs during the late Holocene ( 2800 cal yr BP to today) as seen by intensive erosion and enhanced nutrient supply. Despite this anthropogenic overprinting, the sediment characteristics of Co1260 clearly indicate temperature variations associated with the Medieval Warm Period and the Little Ice Age.

Acknowledgements. This study was funded by the German Research Foundation (DfG) and is part of the project SCOPSCO: Scientific Collaboration on Past Speciation Conditions in Lake Ohrid of the DfG priority programme 1006 "International Continental Drilling Programme (ICDP)" Germany and of the project B2 of the Collaborative Research Centre (CRC) 806 "Our way to Europe - Cultural - Environmental Interaction and Human Mobility in the Late Quaternary". We would like to thank Anne Böhm, Daniel Treu, Frank Schäbitz and Konstantinos Panagiotopoulos for their contributions on the fieldtrip in June 2011. The authors thank Nicole Mankte, Ulrike Patt, Lana König (all University of Cologne), Christopher Kendrick (NIGL), Jonathan Lewis (NIGL) and various students from the University of Cologne for assistance with the laboratory work. Finn Viehberg and Ascelina Hasberg are acknowledged for the determination of the ostracodes in core Co1260. Volker Wennrich contributed with numerous fruitful discussions.

Edited by: M. Magny

\section{References}

Allen, J. R. M., Brandt, U., Brauer, A., Hubberten, H.-W., Huntley, B., Keller, J., Kraml, M., Mackensen, A., Mingram, J., Negendank, J. F. W., Nowaczyk, N. R., Oberhänsli, H., Watts, W. A., Wulf, S., and Zolitschka, B.: Rapid environmental changes in southern Europe during the last glacial period, Nature, 400, 740-743, doi:10.1038/23432, 1999.

Allen, J. R. M., Watts, W. A., McGee, E., and Huntley, B.: Holocene environmental variability-the record from Lago Grande di Monticchio, Italy, Quatern. Int., 88, 69-80, doi:10.1016/s10406182(01)00074-x, 2002.

Arnaud, F., Revel, M., Chapron, E., Desmet, M., and Tribovillard, N.: 7200 years of Rhone river flooding activity in Lake Le Bourget, France: a high-resolution sediment record of NW Alps hydrology, Holocene, 15, 420-428, doi:10.1191/0959683605hl801rp, 2005.

Athanasiadis, N., Tonkov, S., Atanassova, J., and Bozilova, E.: Palynological study of Holocene sediments from Lake Doirani in northern Greece, J. Paleolimnol., 24, 331-342, 2000.

Aufgebauer, A., Panagiotopoulos, K., Wagner, B., Schaebitz, F., Viehberg, F. A., Vogel, H., Zanchetta, G., Sulpizio, R., Leng, M. J., and Damaschke, M.: Climate and environmental change in the Balkans over the last $17 \mathrm{ka}$ recorded in sediments from
Lake Prespa (Albania/F.Y.R. of Macedonia/Greece), Quatern. Int., 274, 122-135, doi:10.1016/j.quaint.2012.02.015, 2012.

Bar-Matthews, M., Ayalon, A., Kaufman, A., and Wasserburg, G. J.: The Eastern Mediterranean paleoclimate as a reflection of regional events: Soreq cave, Israel, Earth Planet. Sc. Lett., 166, 85-95, doi:10.1016/s0012-821x(98)00275-1, 1999.

Beklioglu, M., Altinayar, G., and Tan, C. O.: Water level control over submerged macrophyte development in five shallow lakes of Mediterranean Turkey, Arch. Hydrobiol., 166, 535-556, doi:10.1127/0003-9136/2006/0166-0535, 2006.

Berger, J.-F. and Guilaine, J.: The $8200 \mathrm{calBP}$ abrupt environmental change and the Neolithic transition: A Mediterranean perspective, Quatern. Int., 200, 31-49, doi:10.1016/j.quaint.2008.05.013, 2009.

Bially, A. and Macisaac, H. J.: Fouling mussels (Dreissena spp.) colonize soft sediments in Lake Erie and facilitate benthic invertebrates, Freshwater Biol., 43, 85-97, doi:10.1046/j.13652427.2000.00526.x, 2000.

Blott, S. J. and Pye, K.: GRADISTAT: A grain size distribution and statistics package for the analysis of unconsolidated sediments, Earth Surf. Proc. Land., 26, 1237-1248, 2001.

Bordon, A., Peyron, O., Lézine, A.-M., Brewer, S., and Fouache, E.: Pollen-inferred Late-Glacial and Holocene climate in southern Balkans (Lake Maliq), Quatern. Int., 200, 19-30, doi:10.1016/j.quaint.2008.05.014, 2009.

Cacho, I., Grimalt, J. O., Canals, M., Sbaffi, L., Shackleton, N. J., Schönfeld, J., and Zahn, R.: Variability of the western Mediterranean Sea surface temperature during the last 25,000 years and its connection with the Northern Hemisphere climatic changes, Paleoceanography, 16, 40-52, doi:10.1029/2000pa000502, 2001.

Cohen, H.: Paleolimnology: The History and Evolution of Lake Systems, Oxford University Press, 2003.

Coops, H., Beklioglu, M., and Crisman, T. L.: The role of water-level fluctuations in shallow lake ecosystems workshop conclusions, Hydrobiologia, 506-509, 23-27, doi:10.1023/b:hydr.0000008595.14393.77, 2003.

Croudace, I. W., Rindby, A., and Rothwell, R. G.: ITRAX: description and evaluation of a new multi-function X-ray core scanner, New Tech. Sediment Core Anal., 267, 51-63, 2006.

Crowley, T. J. and Lowery, T. S.: How Warm Was the Medieval Warm Period?, Ambio, 29, 51-54, doi:10.1579/00447447-29.1.51, 2000.

Cvijic, J.: L'ancien Lac Egéen, Annales de Géographie, 20, 233259, 1911.

Denèfle, M., Lézine, A.-M., Fouache, E., and Dufaure, J.-J.: A 12,000-Year Pollen Record from Lake Maliq, Albania, Quaternary Res., 54, 423-432, doi:10.1006/qres.2000.2179, 2000.

Develle, A.-L., Herreros, J., Vidal, L., Sursock, A., and Gasse, F.: Controlling factors on a paleo-lake oxygen isotope record (Yammouneh, Lebanon) since the Last Glacial Maximum, Quaternary Sci. Rev., 29, 865-886, doi:10.1016/j.quascirev.2009.12.005, 2010.

Digerfeldt, G., Olsson, S., and Sandgren, P.: Reconstruction of lake-level changes in lake Xinias, central Greece, during the last 40000 years, Palaeogeogr. Palaeocl., 158, 65-82, doi:10.1016/s0031-0182(00)00029-8, 2000. 
Emeis, K.-C., Struck, U., Schulz, H.-M., Rosenberg, R., Bernasconi, S., Erlenkeuser, H., Sakamoto, T., and MartinezRuiz, F.: Temperature and salinity variations of Mediterranean Sea surface waters over the last 16,000 years from records of planktonic stable oxygen isotopes and alkenone unsaturation ratios, Palaeogeogr. Palaeocl., 158, 259-280, doi:10.1016/S00310182(00)00053-5, 2000.

Griffiths, H. I., Reed, J. M., Leng, M. J., Ryan, S., and Petkovski, S.: The recent palaeocology and conservation status of Balkan Lake Dojran, Biol. Conserv., 104, 35-49, 2002.

Hernández, A., Bao, R., Giralt, S., Leng, M. J., Barker, P. A., Sáez, A., Pueyo, J. J., Moreno, A., Valero-Garcés, B. L., and Sloane, H. J.: The palaeohydrological evolution of Lago Chungará (Andean Altiplano, northern Chile) during the Lateglacial and early Holocene using oxygen isotopes in diatom silica, J. Quaternary Sci., 23, 351-363, doi:10.1002/jqs.1173, 2008.

Joannin, S., Brugiapaglia, E., de Beaulieu, J.-L., Bernardo, L., Magny, M., Peyron, O., Goring, S., and Vannière, B.: Pollenbased reconstruction of Holocene vegetation and climate in southern Italy: the case of Lago Trifoglietti, Clim. Past, 8, 19731996, doi:10.5194/cp-8-1973-2012, 2012.

Kotthoff, U., Müller, U. C., Pross, J., Schmiedl, G., Lawson, I. T., van de Schootbrugge, B., and Schulz, H.: Lateglacial and Holocene vegetation dynamics in the Aegean region: an integrated view based on pollen data from marine and terrestrial archives, Holocene, 18, 1019-1032, doi:10.1177/0959683608095573, 2008a.

Kotthoff, U., Pross, J., Müller, U. C., Peyron, O., Schmiedl, G., Schulz, H., and Bordon, A.: Climate dynamics in the borderlands of the Aegean Sea during formation of sapropel S1 deduced from a marine pollen record, Quaternary Sci. Rev., 27, 832-845, doi:10.1016/j.quascirev.2007.12.001, 2008b.

Kotthoff, U., Koutsodendris, A., Pross, J., Schmiedl, G., Bornemann, A., Kaul, C., Marino, G., Peyron, O., and Schiebel, R.: Impact of Lateglacial cold events on the northern Aegean region reconstructed from marine and terrestrial proxy data, J. Quaternary Sci., 26, 86-96, doi:10.1002/jqs.1430, 2011.

Lamy, F., Arz, H. W., Bond, G. C., Bahr, A., and Pätzold, J.: Multicentennial-scale hydrological changes in the Black Sea and northern Red Sea during the Holocene and the Arctic/North Atlantic Oscillation, Paleoceanography, 21, PA1008, doi:10.1029/2005pa001184, 2006.

Lawson, I., Frogley, M., Bryant, C., Preece, R., and Tzedakis, P.: The Lateglacial and Holocene environmental history of the Ioannina basin, north-west Greece, Quaternary Sci. Rev., 23, 15991625, doi:10.1016/j.quascirev.2004.02.003, 2004.

Lawson, I. T., Al-Omari, S., Tzedakis, P. C., Bryant, C. L., and Christanis, K.: Lateglacial and Holocene vegetation history at Nisi Fen and the Boras mountains, northern Greece, Holocene, $15,873-887,2005$.

Leng, M. J., Roberts, N., Reed, J. M., and Sloane, H. J.: Late Quaternary palaeohydrology of the Konya Basin, Turkey, based on isotope studies of modern hydrology and lacustrine carbonates, J. Paleolimnol., 22, 187-204, doi:10.1023/a:1008024127346, 1999.

Leng, M. J. and Marshall, J. D.: Palaeoclimate interpretation of stable isotope data from lake sediment archives, Quaternary Sci. Rev., 23, 811-831, doi:10.1016/j.quascirev.2003.06.012, 2004.
Leng, M. J., Metcalfe, S., and Davies, S.: Investigating Late Holocene Climate Variability in Central Mexico using Carbon Isotope Ratios in Organic Materials and Oxygen Isotope Ratios from Diatom Silica within Lacustrine Sediments, J. Paleolimnol., 34, 413-431, doi:10.1007/s10933-005-6748-8, 2005.

Leng, M. J., Baneschi, I., Zanchetta, G., Jex, C. N., Wagner, B., and Vogel, H.: Late Quaternary palaeoenvironmental reconstruction from Lakes Ohrid and Prespa (Macedonia/Albania border) using stable isotopes, Biogeosciences, 7, 3109-3122, doi:10.5194/bg7-3109-2010, 2010

Leng, M. J., Wagner, B., Boehm, A., Panagiotopoulos, K., Vane, C. H., Snelling, A., Haidon, C., Woodley, E., Vogel, H., Zanchetta, G., and Baneschi, I.: Understanding past climatic and hydrological variability in the Mediterranean from lake sediment isotope and geochemical data, Quaternary Sci. Rev., doi:10.1016/j.quascirev.2012.07.015, in press, 2012.

Magny, M., Bégeot, C., Guiot, J., and Peyron, O.: Contrasting patterns of hydrological changes in Europe in response to Holocene climate cooling phases, Quaternary Sci. Rev., 22, 1589-1596, doi:10.1016/s0277-3791(03)00131-8, 2003.

Magny, M., Vannière, B., Zanchetta, G., Fouache, E., Touchais, G., Petrika, L., Coussot, C., Walter-Simonnet, A.-V., and Arnaud, F.: Possible complexity of the climatic event around 4300-3800 cal. BP in the central and western Mediterranean, Holocene, 19, 823-833, doi:10.1177/0959683609337360, 2009.

Manley, R., Spirovska, M., and Andovska, S.: Water balance model of Lake Dojran, BALWOIS Conference Publications, Ohrid, FYROM, 27-31 May 2008.

Matzinger, A., Jordanoski, M., Veljanoska-Sarafiloska, E., Sturm, M., Müller, B., and Wüest, A.: Is Lake Prespa Jeopardizing the Ecosystem of Ancient Lake Ohrid?, Hydrobiologia, 553, 89109, doi:10.1007/s10750-005-6427-9, 2006.

Meisch, C.: Freshwater Ostracoda of Western and Central Europe, Süßwasserfauna von Mitteleuropa, edited by: Schwoerbel, J. and Zwick, P., Akademischer Verlag Spektrum, Heidelberg, 2000.

Mercone, D., Thomson, J., Croudace, I. W., Siani, G., Paterne, M., and Troelstra, S.: Duration of S1, the most recent sapropel in the eastern Mediterranean Sea, as indicated by accelerator mass spectrometry radiocarbon and geochemical evidence, Paleoceanography, 15, 336-347, doi:10.1029/1999pa000397, 2000.

Müller, A.: Late- and Postglacial Sea-Level Change and Paleoenvironments in the Oder Estuary, Southern Baltic Sea, Quaternary Res., 55, 86-96, doi:10.1006/qres.2000.2189, 2001.

Panagiotopoulos, K., Aufgebauer, A., Schäbitz, F., and Wagner, B.: Vegetation and climate history of the Lake Prespa region since the Lateglacial, Quatern. Int., doi:10.1016/j.quaint.2012.05.048, in press, 2012.

Peyron, O., Goring, S., Dormoy, I., Kotthoff, U., Pross, J., de Beaulieu, J.-L., Drescher-Schneider, R., Vannière, B., and Magny, M.: Holocene seasonality changes in the central Mediterranean region reconstructed from the pollen sequences of Lake Accesa (Italy) and Tenaghi Philippon (Greece), Holocene, 21, 131-146, doi:10.1177/0959683610384162, 2011.

Pross, J., Kotthoff, U., Müller, U. C., Peyron, O., Dormoy, I., Schmiedl, G., Kalaitzidis, S., and Smith, A. M.: Massive perturbation in terrestrial ecosystems of the Eastern Mediterranean region associated with the $8.2 \mathrm{kyr}$ B.P. climatic event, Geology, 37, 887-890, doi:10.1130/g25739a.1, 2009. 
Ramsey, B. C.: Radiocarbon Dating: Revolutions in Understanding, Archaeometry, 50, 249-275, doi:10.1111/j.14754754.2008.00394.x, 2008.

Reimer, P. J., Baillie, M. G. L., Bard, E., Bayliss, A., Beck, J. W., Blackwell, P. G., Ramsey, C. B., Buck, C. E., Burr, G. S., Edwards, R. L., Friedrich, M., Grootes, P. M., Guilderson, T. P., Hajdas, I., Heaton, T. J., Hogg, A. G., Hughen, K. A., Kaiser, K. F., Kromer, B., McCormac, F. G., Manning, S. W., Reimer, R. W., Richards, D. A., Southon, J. R., Talamo, S., Turney, C. S. M., van der Plicht, J., and Weyhenmeyer, C. E.: IntCal09 and Marine09 Radiocarbon Age Calibration Curves, 0-50,000 Years cal BP, Radiocarbon, 51, 1111-1150, 2009.

Rethemeyer, J., Fülöp, R. H., Höfle, S., Wacker, L., Heinze, S., Hajdas, I., Patt, U., König, S., Stapper, B., and Dewald, A.: Status report on sample preparation facilities for ${ }^{14} \mathrm{C}$ analysis at the new CologneAMS center, Nucl. Instrum. Meth. Phys. Res. B, 294, 168-172, doi:10.1016/j.nimb.2012.02.012, in press, 2013.

Roberts, N., Jones, M. D., Benkaddour, A., Eastwood, W. J., Filippi, M. L., Frogley, M. R., Lamb, H. F., Leng, M. J., Reed, J. M., Stein, M., Stevens, L., Valero-Garcés, B., and Zanchetta, G.: Stable isotope records of Late Quaternary climate and hydrology from Mediterranean lakes: the ISOMED synthesis, Quaternary Sci. Rev., 27, 2426-2441, doi:10.1016/j.quascirev.2008.09.005, 2008.

Rohling, E. J. and Palike, H.: Centennial-scale climate cooling with a sudden cold event around 8,200 years ago, Nature, 434, 975979, doi:10.1038/nature03421, 2005.

Rossignol-Strick, M.: Late Quaternary climate in the Eastern Mediterranean Region, Paléorient, 19, 135-152, doi:10.3406/paleo.1993.4588, 1993.

Schilman, B., Bar-Matthews, M., Almogi-Labin, A., and Luz, B.: Global climate instability reflected by Eastern Mediterranean marine records during the late Holocene, Palaeogeogr. Palaeocl., 176, 157-176, doi:10.1016/s0031-0182(01)00336-4, 2001.

Schmiedl, G., Kuhnt, T., Ehrmann, W., Emeis, K.-C., Hamann, Y., Kotthoff, U., Dulski, P., and Pross, J.: Climatic forcing of eastern Mediterranean deep-water formation and benthic ecosystems during the past 22000 years, Quaternary Sci. Rev., 29, 30063020, doi:10.1016/j.quascirev.2010.07.002, 2010.

Siani, G., Magny, M., Paterne, M., Debret, M., and Fontugne, M.: Paleohydrology reconstruction and Holocene climate variability in the South Adriatic Sea, Clim. Past Discuss., 8, 4357-4399, doi:10.5194/cpd-8-4357-2012, 2012.

Sotiria, K. and Petkovski, S.: Lake Doiran - An overview of the current situation, Greek Biotope/Wetland Centre (EKBY), Society for the Investigation and Conservation of Biodiversity and the Sustainable Development of Natural Ecosystems (BIOECO), Thermi, 1-117, 2004.

Stankovic, S.: Sur les particularités limnologiques des lacs égéens, Verhandlungen der internationalen Vereinigung für theoretische und angewandte Limnologie, 5, 138-146, 1931.

Stojanov, R. and Micevski, E.: Geology of Lake Doiran and its surrounding, Contributions of the Macedonian Academy of Sciences and Arts, Section of Biological and Medical Sciences, 10, 37-52, 1989.

Stuiver, M. and Reimer, P. J.: Extended (super 14) C data base and revised CALIB 3.0 (super 14) $\mathrm{C}$ age calibration program, Radiocarbon, 35, 215-230, 1993.
Tzedakis, P. C.: Seven ambiguities in the Mediterranean palaeoenvironmental narrative, Quaternary Sci. Rev., 26, 2042-2066, doi:10.1016/j.quascirev.2007.03.014, 2007.

Valsecchi, V., Sanchez Goñi, M. F., and Londeix, L.: Vegetation dynamics in the Northeastern Mediterranean region during the past $23000 \mathrm{yr}$ : insights from a new pollen record from the Sea of Marmara, Clim. Past, 8, 1941-1956, doi:10.5194/cp-8-19412012, 2012.

Veljanoska-Sarafiloska, E., Stafilov, T., and Jordanoski, M.: Distribution of DDT Metabolites in the sediment and muscle fish tissue from agriculturally impacted Lake Dojran (Macedonia/Greece), Fresenius Environ. Bull., 20, 2027-2035, 2001.

Vogel, H., Wagner, B., Zanchetta, G., Sulpizio, R., and Rosén, P.: A paleoclimate record with tephrochronological age control for the last glacial-interglacial cycle from Lake Ohrid, Albania and Macedonia, J. Paleolimnol., 44, 295-310, doi:10.1007/s10933009-9404-x, 2010a

Vogel, H., Zanchetta, G., Sulpizio, R., Wagner, B., and Nowaczyk, N.: A tephrostratigraphic record for the last glacial-interglacial cycle from Lake Ohrid, Albania and Macedonia, J. Quaternary Sci., 25, 320-338, doi:10.1002/jqs.1311, 2010 b.

Wagner, B., Melles, M., Doran, P. T., Kenig, F., Forman, S. L., Pierau, R., and Allen, P.: Glacial and postglacial sedimentation in the Fryxell basin, Taylor Valley, southern Victoria Land, Antarctica, Palaeogeogr. Palaeoecl., 241, 320-337, doi:10.1016/j.palaeo.2006.04.003, 2006.

Wagner, B., Lotter, A. F., Nowaczyk, N., Reed, J. M., Schwalb, A., Sulpizio, R., Valsecchi, V., Wessels, M., and Zanchetta, G.: A 40,000-year record of environmental change from ancient Lake Ohrid (Albania and Macedonia), J. Paleolimnol., 41, 407-430, doi:10.1007/s10933-008-9234-2, 2009.

Wagner, B., Vogel, H., Zanchetta, G., and Sulpizio, R.: Environmental change within the Balkan region during the past ca. $50 \mathrm{ka}$ recorded in the sediments from lakes Prespa and Ohrid, Biogeosciences, 7, 3187-3198, doi:10.5194/bg-7-3187-2010, 2010.

Wagner, B., Aufgebauer, A., Vogel, H., Zanchetta, G., Sulpizio, R., and Damaschke, M.: Late Pleistocene and Holocene contourite drift in Lake Prespa (Albania/F.Y.R. of Macedonia/Greece), Quatern. Int., 274, 112-121, doi:10.1016/j.quaint.2012.02.016, 2012.

Wang, W., Wang, D., and Yin, C.: A Field Study on the Hydrochemistry of Land/Inland Water Ecotones with Reed Domination, Acta Hydrochim. Hydrobiol., 30, 117-127, 2002.

Weiss, H. and Bradley, R. S.: What Drives Societal Collapse?, Science, 291, 609-610, doi:10.1126/science.1058775, 2001.

Wick, L., Lemcke, G., and Sturm, M.: Evidence of Lateglacial and Holocene climatic change and human impact in eastern Anatolia: high-resolution pollen, charcoal, isotopic and geochemical records from the laminated sediments of Lake Van, Turkey, Holocene, 13, 665-675, doi:10.1191/0959683603hl653rp, 2003.

Willis, K. J.: The vegetational history of the Balkans, Quaternary Sci. Rev., 13, 769-788, doi:10.1016/0277-3791(94)90104$\mathrm{x}, 1994$.

Yin, C. and Lan, Z.: The nutrient retention by ecotone wetlands and their modification for Baiyangdian lake restoration, Water Sci. Technol., 32, 159-167, doi:10.1016/0273-1223(95)00616-8, 1995. 
Zacharias, I., Bertachas, I., Skoulikidis, N., and Koussouris, T.: Greek Lakes: Limnological overview, Lakes Reserv. Res. Manage., 7, 55-62, doi:10.1046/j.1440-1770.2002.00171.x, 2002.

Zanchetta, G., Drysdale, R. N., Hellstrom, J. C., Fallick, A. E., Isola, I., Gagan, M. K., and Pareschi, M. T.: Enhanced rainfall in the Western Mediterranean during deposition of sapropel S1: stalagmite evidence from Corchia cave (Central Italy), Quaternary Sci. Rev., 26, 279-286, doi:10.1016/j.quascirev.2006.12.003, 2007a.
Zanchetta, G., Borghini, A., Fallick, A., Bonadonna, F., and Leone, G.: Late Quaternary palaeohydrology of Lake Pergusa (Sicily, southern Italy) as inferred by stable isotopes of lacustrine carbonates, J. Paleolimnol., 38, 227-239, doi:10.1007/s10933-0069070-1, 2007b. 